\title{
Team formation processes in new ventures
}

\author{
Lukas Held • Andrea M. Herrmann • \\ Allard van Mossel
}

Accepted: 30 November 2017 / Published online: 8 March 2018

(C) The Author(s) 2018. This article is an open access publication

\begin{abstract}
While entrepreneurship research theorizing about the team formation in start-up ventures exists, such studies mostly focus on different outcomes of team formation, for example the number of employees. Questions about how team formation processes unfold and the factors, such as labor-market institutions, influencing their evolvement remain unanswered. To address this research gap, we analyze the venture creation processes of 344 ventures in Germany and the USA, offering particularly typical examples of countries with regulated and deregulated labor-market institutions respectively. Based on optimal matching techniques, we illustrate how team formation processes differ over time in terms of founder and employee involvement and the hiring of service providers. Furthermore, we use binary logistic regressions to identify the extent to which national labor-market institutions account for these differences.
\end{abstract}

Keywords New venture creation - Team formation . Entrepreneurship · Varieties-of-capitalism · Optimal matching $\cdot$ Labor-market institutions

JEL classification $\mathrm{L} 26 \cdot \mathrm{M} 13 \cdot \mathrm{M} 54$

L. Held $(\bowtie) \cdot$ A. M. Herrmann · A. van Mossel Innovation Studies, Copernicus Institute of Sustainable Development, Utrecht University, Utrecht, Netherlands e-mail: 1.held@uu.nl

\section{Introduction}

With his seminal article "Who is the entrepreneur is asking the wrong question", Gartner (1988) initiated a new paradigm in entrepreneurship research. Instead of focusing on the characteristics of entrepreneurs, scholars began to research the entrepreneurial process. While it is now widely accepted that entrepreneurship is a process that unfolds over time rather than a singular act, different conceptualizations of the process have emerged (Moroz and Hindle 2012). We here follow the conceptualizations of entrepreneurship as the process of venture creation (VCP), a conceptualization now considered to be central to entrepreneurship research (Davidsson and Gordon 2012).

Among those who understand entrepreneurship as the creation of ventures, a variety of ways to define and operationalize VCPs exist and our knowledge about it remains limited (Samuelsson and Davidsson 2009). The literature on VCPs and venture growth has produced a variety of perspectives on how ventures are created, of which the two most prominent ones are stage-based models and activity-based models (Moroz and Hindle 2012). Stage-based models postulate that all ventures, just like organisms, go through the same, predetermined stages in their development (Levie and Lichtenstein 2010). Hence, the underlying concept of VCPs is a passive one that assumes a "natural," almost automatic progression through the different stages, thereby putting little emphasis on the activities and choices of the entrepreneur. In contrast, 
activity-based models conceive a VCP as the number and sequence of singular gestation activities occurring throughout the VCP (Carter et al. 1996). The result is a rather active VCP concept explicitly focusing on the actions of the entrepreneur. In fact, this approach defines the VCP as the accumulation of singular activities that the entrepreneur chooses to undertake from an eclectic list of gestation activities. Despite these substantial differences, neither perspective has yet produced a coherent, widely accepted conceptualization of the VCP (Levie and Lichtenstein 2010; Davidsson and Gordon 2012).

The most recent literature on venture creation argues that this conceptual failure has methodological origins: existing studies do not analyze the VCP as the unit of analysis but rather treat entrepreneurship as a linear succession of distinct stages or a number of singular gestation activities (Garnsey et al. 2006; McMullen and Dimov 2013; Hjorth et al. 2015). This often leads to the use of methods not optimal for studying processes (Van de Ven and Engleman 2004; Gordon 2012; Langley et al. 2013): More concretely, Aldrich (2001) distinguishes between outcome-driven (or variance) explanations and event-driven (or process) explanations. While variance-driven studies are suitable to explain change through deterministic causation, eventdriven studies consider every action and how they form one process unit (Poole et al. 2000). Because the vast majority of publications have employed variance explanations, they are able to answer questions about antecedents and outcomes of the entrepreneurial process, but little progress has been made to explain how said process unfolds (Van de Ven and Engleman 2004; Ruef 2005).

Furthermore, it has been argued that important heterogeneities between different ventures and venture creation contexts make it difficult to uncover patterns in VCPs. In order to be able to produce meaningful descriptions of VCPs, different characteristics of ventures, as well as the context of their creation, need to be taken into account and controlled for (Samuelsson and Davidsson 2009; Gartner and Shaver 2012).

Taken together, the different literature strands on VCPs thus provide inconclusive results about whether VCPs are "order or chaos." Yet, this question has become ever more important in view of the increasing number of countries that implement policies to stimulate economic growth through entrepreneurship. While the differences in the level of entrepreneurial activity between countries are well documented, the lack of knowledge about VCPs means that we do not know whether the processes underpinning entrepreneurial activity also differ between countries. We need to understand if, and how, national institutions shape VCPs in order to decide whether one optimal blueprint for the stimulation of entrepreneurship exists, or whether entrepreneurship policies have to be adapted to VCPs shaped by national institutions.

In order to address this research gap, we focus on the most essential process within venture creation, namely the one of team formation (TFP). The process of team formation describes the assembly of a venture's most crucial resource: human capital. A great number of studies have found that the human capital embodied by a venture's founders is the most significant predictor for a venture's survival and growth (Bates 1990; Cooper et al. 1994; Bosma et al. 2004; Delmar and Shane 2004; Colombo and Grilli 2005). Building on these insights, recent studies on team formation argue that employees contribute in similar fashion to a venture's human capital and subsequently its survival (Weber and Zulehner 2010; Koch et al. 2013; Dahl et al. 2015; Coad et al. 2016). Consequently, we conceptualize the team formation process as the time commitments of founders, employees, and service providers at any time between inception of the venture and the point it reaches profitability or exits.

Accordingly, our research addresses the above gaps in the VCP literature by asking:

Do distinct types of team formation processes exist, how do they differ and which structural characteristics can explain these differences?

Our paper answers these questions by taking a new methodological and empirical approach: we apply optimal matching $(\mathrm{OM})$ and clustering techniques to the novel data of the "Perfect Timing" dataset, reporting the venture creation processes of 344 start-up ventures on a monthly basis. Owing to $\mathrm{OM}$ analyses and clustering techniques, we are able to study entire VCPs as the unit of analysis and thus, to explore distinct team formation processes on the basis of the team formation activities undertaken, their timing, and duration.

In summary, these $\mathrm{OM}$ analyses demonstrate that team formation is "order" rather than chaos as distinct 
temporal patterns of team formation exist with regard to the time commitment of founders as well as the extent to which employees and service providers are hired. Importantly, we are able to explore a distinct number of approaches for each of these three teamformation dimensions. Furthermore, correlation and regression analyses illustrate that the approaches in one dimension are only weakly correlated to the approaches of the two other dimensions: We observe additivity effects between founder involvement and employee hiring, while the data indicates that substitution effects exist between the hiring of employees and service provider engagement. Finally, binary logistic regression analyses reveal that structural characteristics, in particular the venture's institutional environment and innovativeness, influence which team formation approach is pursued.

To illustrate these findings, the paper proceeds as follows: In Section 2, we begin with a short review of the literatures on entrepreneurial processes in general and team formation in particular. In doing so, we highlight the opposing views of the stagebased and activity-based approaches. In Section 3, we present the data and methodology employed, while we present our results in Section 4. In Section 5, we discuss these findings and their limitations in the context of previous research and the methodology used. Importantly, we also reflect on the opportunities for future research based on OM techniques.

\section{Theory}

In the following section, we introduce the theoretical building blocks required to explore team formation processes in ventures. As illustrated in Fig. 1, we summarize in a first step the literatures discussing different types of team formation. Focusing on its three core dimensions - founder, employees, and service provider involvement-we formulate Proposition 1: that distinct types of team formation exist for each dimension. With that in mind, we review in a second step the literature that discusses possible interdependences between approaches (Proposition 2). In a last step, we review the literatures on possible influences of structural characteristics upon team formation, in particular labor-market regulation, nature of the venture's good, and innovativeness (Propositions 3-5).
What do the different literature strands on team formation processes (TFPs) teach us about how these may evolve? Is team formation random or evolving along systematic trajectories? The stage-based literature was the first to address this question. Here, venture creation in general, as well as team formation in particular, are commonly depicted as a series of prescribed stages (Phelps et al. 2007; Levie and Lichtenstein 2010). With regard to team formation, many stage models describe a process of continuous growth which, in the beginning, is centered on the role of the founder(s). Kazanjian and Drazin (1990) and Kaulio (2003), for example, posit that, during the first stage of venture creation, the founder(s) work on a prototype or idea. Once the prototype has been created, more founders or core employees join the team in order to work on the products' commercialization during the second stage. Once a commercially viable product has been created, the venture enters into the stage of growth, during which more employees and service providers join to the team. Hence, team formation is described as a linear process during which the team grows from one to many founders who increasingly hire employees as time goes by.

The gestation activity literature instead portrays team formation as non-linear processes which are characterized by a variety of activities such as organizing the founder team, switching between part- and full-time work, and hiring employees, all of which can occur at different moments (Reynolds and Miller 1992; Gatewood et al. 1995; Carter et al. 1996). While these studies establish that more than one team formation process exists, they only provide snapshots into the frequencies with which different team formation activities take place at different moments of the process.

To give some examples, Gartner et al. (2004) analyze the first start-up activity carried out by new ventures and find that only few ventures start with activities related to team formation, such as "organizing the start-up team" $(6 \%)$, getting "devoted full-time" $(2 \%)$, or "hiring employees" $(<1 \%)$. Another study investigates the sequence of individual start-up activities, distinguishing between successful, interrupted, and ongoing venture creation processes: In this study, Carter et al. (1996) illustrate that the majority of successful ventures organize the founder team in the second quarter after venture inception, while at least one founder switches to fulltime work at the same time. In the following quarter, the first employee is hired. In contrast, founders who give up on venture creation mostly organize the founder team 


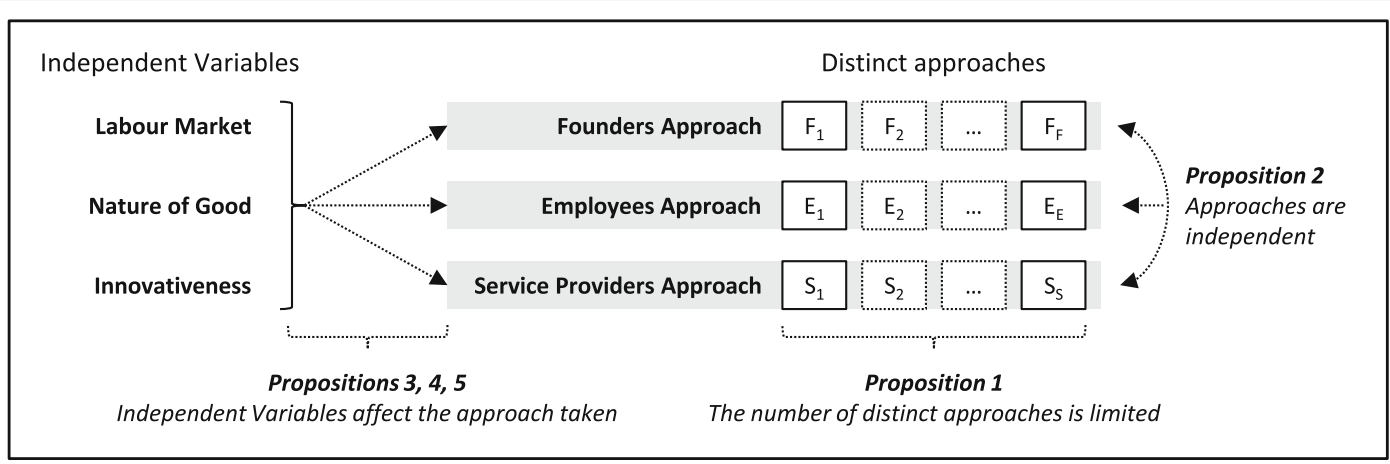

Fig. 1 Theoretical building blocks of team formation processes

in the first month after inception, but wait for 1 year before switching to full-time work. By contrast, founders of unsuccessful ventures, characterized by ongoing venture creation processes, organize the founder team in the second quarter after venture inception but never switch to full-time work, nor hire any employees.

In summary, while some scattered evidence exists, systematic insights into how team formation evolves over time with regard to founder involvement, the hiring of employees, or other types of labor are still missing (Gordon 2012; Jaspers and Hak 2013). That said, it is interesting to note that the activity-based literature agrees with the stage-based literature in that team formation process are not random but follow distinct patterns. Yet, contrary to the stage-based literature, the activity-based literature holds that these patterns do mostly not follow a linear growth process and are context-dependent (Liao et al. 2005; Gartner and Shaver 2012).

Beyond the stage- and activity-based literatures, various research strands provide insights into individual aspects of team formation without explicitly positioning their findings within the overall team formation process. These aspects include the development of founder teams, the time commitment of founders including part-time entrepreneurs as well as their transition to full-time entrepreneurship, the hiring of employees, and the engaging of service providers.

Those few studies that analyze the development of founder teams illustrate that founder exit is more likely than founder entry throughout the TFP (Hellerstedt 2009). Furthermore, the initial number of founders seems to influence subsequent founder exit and entry. However, the exact effect remains unclear: while some authors argue that the likelihood of founders exiting or additional founders joining the team is higher for bigger teams (Chandler et al. 2005; Hellerstedt 2009), others observe the opposite effect (Ucbasaran et al. 2003). Yet researchers, investigating founder team development, largely concur in their observation that the number of founders overall remains stable throughout the TFP in most ventures (Hellerstedt 2009).

A further research strand, known as the literature on part-time or hybrid entrepreneurship, illustrates that not only the number of founders can vary throughout TFPs but also their time commitment. Wennberg et al. (2006) were one of the first to argue that besides the traditional dichotomy of being an employee or a full-time entrepreneur, the possibility of creating a venture in part-time exists. Several empirical studies show that a significant amount of founders actually choose to do so, whereby the exact amount of part-time founders (or hybrid entrepreneurs) varies strongly between countries. In Germany, for example, $64 \%$ of ventures created in 2013 were set-up by part-time founders (Metzger 2014). The opportunity to test one's own abilities as a founder, while reducing the financial and labor-market risks related to full-time entrepreneurship, is mentioned among the most important motives for part-time entrepreneurship (Folta et al. 2010; Raffiee and Feng 2014).

More recent studies on hybrid entrepreneurship show that entrepreneurs do not necessarily remain part- or full-time entrepreneurs for the entire duration of the TFP, but increase or decrease their time commitments throughout the TFP (Folta et al. 2010; Block and Landgraf 2016). For example, Block and Landgraf (2016) find that $20 \%$ of full-time founders in their study of German founders initially started out as part-time founders, whereby it remains unknown when these switches from part-time to full-time entrepreneurship occurred. 
Even though considered a key decision for young ventures, surprisingly little is known about the hiring of employees (Cardon and Stevens 2004). One problem is that most studies exploring the initial size of ventures ignore (very) small ventures which arguably make up the vast majority of ventures. Consequently, only scattered evidence exists about the extent and timing of employee hiring. The study by Melillo et al. (2013) on Swedish ventures in knowledge-intense industries (1994-2001) encompasses ventures of all sizes, including one-person ventures. It comes to the conclusion that $93 \%$ of ventures do not hire any employee during the first year of their existence. The remaining $7 \%$ of ventures involve one $(5.3 \%)$, two $(.89 \%)$, three $(.4 \%)$, or four or more employees $(.54 \%)$ during the same time span. Following Swedish ventures created in 1998 over the first 2 years of their existence, Delmar and Shane (2003) report the following development of average employee number: At their inception, ventures hire an average employee capacity of .17 FTE, which increases over the following 6 months to .51 FTE. In month 12, the average employee capacity hired further increases slowly to $.73 \mathrm{FTE}$, before jumping up to $3.2 \mathrm{FTE}$ in month 18. Interestingly, the average employee number hired then drops to 1.62 FTE in month 24, i.e., the last observation point. Finally, the findings of Cooper et al. (1989) illustrate that US ventures which in the first year hire three employees or less grow more strongly during the remaining TFP, both in relative and absolute terms, than ventures that start out with more employees.

The existing evidence regarding the involvement of external service providers in team formation is even more scattered than for the hiring of employees, whereby scholars agree about the importance of service providers as an external source of labor: Cassar and Ittner (2009) demonstrate that a large number of new ventures in the US engage, or plan to engage, accountants $(64 \%)$ and lawyers $(46 \%)$ in their quest for profitability. At what point in the TFP the initial engaging of accountants occurs seems to strongly coincide with events like initial sale or opening of the ventures bank account. Furthermore, Bennett et al. (1999) show that small- and medium-sized companies in the UK tend to make use of multiple external service providers and that the use of external service providers is positively related to the number of employees: the higher the number of employees, the more likely that a service providers is engage.
Cooper et al. (1989) come to the same conclusion in the US context.

While the existing studies provide valuable insights into TFPs, indicating that team formation in ventures is neither chaos nor unidimensional order, it remains unclear what and how many distinct approaches to TFP exist, and what they look like. Based on the available evidence on TFPs, we expect that

Proposition 1: distinct types of team formation rather than unsystematic approaches exist in which (a) founders commit themselves to venture creation, (b) employees are hired, and (c) service providers are engaged during the venture creation process.

If we are right in that team formation processes follow distinct pathways with regard to founder involvement, employees hiring, and the engagement of service providers, the question arises of how do these three channels relate to each other. Does the way in which founders contribute to venture creation influence the extent and timing of employee hiring and service provider engagement? And does the hiring of employees correlate with the engagement of service providers: For example, can we observe substitution or additive effects with regard to the involvement of internal labor (founders and employees) and external labor (service providers) throughout the TFP? Or are the approach to founder involvement, employee hiring, and service provider engagement unrelated to each other?

While specific research into the relationship between founder, employee, and service provider involvement during venture creation does not exist, different and often contradicting approaches to aggregate team formation have been described in the literature. On the one hand, studies describe additive effects in high-growth ventures where higher founder commitment cooccurs with extensive employee growth and service provider engagement (Cooper et al. 1989; Reynolds and White 1997). On the other hand, scholars observe substitution effects in ventures with growth aspirations between the hiring of employees and engaging service providers as ventures try to avoid high ancillary wage costs and employee protection (Román et al. 2011). 
In line with these insights, we expect that

Proposition 2: (a) the time commitment of founders and the hiring of employees is additive, while (b) the time commitment of founders and service providers is not related, whereas (c) the hiring of employees and service providers is substitutive throughout the venture creation process.

Should we be able to identify systematically different approaches to founder, employee, and service provider involvement during venture creation, the question arises how to explain which approach is chosen: under which conditions do founders engage in one rather than another way of setting up their venture? And under which conditions do they hire no, some, or many employees and service providers respectively? In other words, which influence does a venture's context and its characteristics have on the approaches chosen toward team formation? A wide variety of VCP studies have pointed out that part of the struggle to establish coherent patterns in VCP stems from the negligence of differences in the context and characteristics of the studied ventures (Van de Ven and Engleman 2004; Ruef 2005; Gartner and Shaver 2012). Among the most prominent factors identified in the entrepreneurship literature are national institutions, a venture's innovation strategy, and the type of product developed (Ruef 2005; Samuelsson and Davidsson 2009).

To begin with, the influence of national institutions on venture creation processes (in our case the influence of labor-market institutions on team formation processes) the "Varieties-of-Capitalism" (VoC) literature has long established that companies follow distinct human resource approaches as a reaction to different types of labor-market regulations (Estévez-Abe and Iversen 2001; Hall and Soskice 2001a; Herrmann and Peine 2011). Other than a recent study by Dilli et al. (2018), these studies focus on incumbent firms rather than startup ventures, their reasoning however is compatible with various entrepreneurship studies on how the rigidity of national labor-market institutions may influence team formation in new ventures.

With regard to institutional influences on founder involvement, real-options theory assumes that an individual will choose entrepreneurship over dependent employment if the potential rewards of starting a venture outweigh the related risks (Wennberg et al. 2006). In line with the reasoning of the $\mathrm{VoC}$ literature, this implies that strong employment protection-in the form of strong unions, centralized wage bargaining, long notice periods, and limited reasons for dismissal-makes dependent employment more attractive vis-à-vis entrepreneurship (Wennekers et al. 2005). At the same time, strong labor-market regulations also makes the hiring of employees relatively more costly for entrepreneurs which, in turn, makes entrepreneurship less attractive (van Stel et al. 2007; Henrekson et al. 2010). Both effects imply that the level of certainty about a venture's profitability has to be higher in rigid labor-markets than in liberal ones for prospective founders to give up their jobs in favor of committing themselves to venture creation (Román et al. 2013). One way of increasing certainty about one's entrepreneurial abilities and the venture's profitability, without giving up the benefits of dependent employment, is part-time entrepreneurship (Raffiee and Feng 2014). Hence, part-time entrepreneurship seems more likely in regulated than in flexible labor markets.

With regard to institutional influences on employee hiring, the $\mathrm{VoC}$ reasoning is compatible with the insights of several entrepreneurship studies: that rigid labormarket institutions reduce a venture's growth ambitions and the extent to which employees are hired (Bosma and Levie 2009; Baughn et al. 2010): strong employment protection reduces the venture's flexibility to dismiss employees in response to changes in the business environment or in case of low employee performance (Estévez-Abe and Iversen 2001; Hall and Soskice 2001b). This, in turn, increases the risks of hiring employees (Davidsson and Henrekson 2002; Henrekson et al. 2010). Accordingly, Bornhäll et al. (2016) point to the Swedish case, where employment protection (in this case exemptions from the last-in/first-out principle) becomes more severe once a venture employs more than ten workers: accordingly, the authors illustrate that the likelihood of hiring employees decreases significantly once ventures come close to this threshold which, in turn, illustrates the negative influence of rigid labormarket institutions on employee hiring.

Similarly, labor-market institutions have been found to influence the attractiveness of engaging external service providers compared to employees. Based on a principal-agent model, Parker (2010) illustrates that rigid labor-market institutions increase the tendency of firms to hire external service providers in order to 
circumvent employment constraints, such as payroll taxes. In line with these findings, Román et al. (2011) show that rigid labor-market institutions encourage companies to re-hire employees as self-employed service providers instead of extending employment contracts. Given that employment protection becomes more severe once ventures reach specific employee thresholds, and given that the consequences of hiring underperforming employees are more severe for small ventures than for large firms (Davidsson and Henrekson 2002), it can be expected that the preference of hiring service providers rather than employees is particularly acute in new ventures.

The above reasoning leads us to expect that

Proposition 3: national labor market institutions influence (a) the approach of founders toward committing themselves to venture creation, (b) the approach of founders toward hiring employees, and (c) engaging service providers during venture creation.

Also, the nature of the good (product or service) developed has been found to influence the number and type of gestation activities carried out - and thus the participation of founders and employees - during venture creation (Gordon and Davidsson 2013). On the one hand, ventures developing products require more resources than service developers (Ruef 2005); on the other, they are also more likely to pursue growth strategies due to their stronger need to achieve economies of scale (Audretsch et al. 2004). Consequently, a study of the Dutch hospitality sector finds that the growth patterns of small service ventures differ from those of small manufacturing ventures (Audretsch et al. 2004).

With regard to the involvement of founders in venture creation, Petrova (2012) explains how the more limited need for resources and slow growth trajectories lead to significantly higher shares of part-time entrepreneurs running business service rather than manufacturing ventures. These findings are supported by Germany's self-employment statistics in 2008, where the share of part-time entrepreneurs amounted to $15 \%$ in manufacturing and $36.2 \%$ in service ventures (Buddensiek et al. 2013).

With regard to the hiring of employees, Fritsch and Weyh (2006) illustrate that, on average, German manufacturing ventures do not only start out with more employees than their service providing counterparts; they also follow different growth trajectories during their first years of existence, so that the number of employees increases more substantially in product manufacturing than in service-providing ventures.

The above reasoning leads us to expect that

Proposition 4: the nature of a good a venture intends to sell influences (a) the approach of founders toward committing themselves to venture creation, (b) the approach of founders toward hiring employees, and (c) engaging service providers during the venture creation.

Finally, the innovativeness of a venture's business idea is also likely to influence the team formation approaches chosen. The innovation literature highlights that those ventures which develop new business ideas, rather than imitating existing ones, can either be radically or incrementally innovative. While incremental innovators improve existing (technologies of) business ideas, radical innovators develop entirely new ones (Abernathy and Clark 1985). Depending on the type of innovation a venture develops, it faces different challenges (Amason et al. 2006; Samuelsson and Davidsson 2009). Ventures developing radical innovations mostly require tacit knowledge (Mascitelli 2000), because "most knowledge is created and stored within individuals" (Grant 1997). Therefore, the configuration of ventures' internal labor resources, that is founders and employees, is especially relevant for innovative ventures (Andries and Czarnitzki 2014).

With regard to founder involvement, this implies that founders need to carry out more and a broader range of gestation activities (Amason et al. 2006; Samuelsson and Davidsson 2009) in order to master the higher levels of uncertainty and complexity related to radical innovations (Liao and Welsch 2008; Samuelsson and Davidsson 2009). Consequently, ventures developing radically innovative business ideas are more likely to be created by large founder teams, because they tend to have more, and more diverse, resources at their disposal (Eisenhardt et al. 1990; Wiersema and Bantel 1992).

In line with this reasoning, ventures developing radical innovations also hire employees earlier and more substantially (Freel and Robson 2004). Given that the building up of tacit knowledge is both cost- and timeintense, it only pays off for ventures if employees are 
retained over longer time periods (Becker 1962; Virtanen et al. 2003). Consequently, radically innovative ventures can be expected to retain their employees for longer time periods than incrementally innovative ventures or imitators.

Accordingly, innovative ventures rely less on external service providers than imitative ventures, because the latter are more willing to accept limited tacit knowledge in return for the increased flexibility to increase, or decrease, their pool of external service providers (Chandler et al. 2009).

The above reasoning leads us to expect that

Proposition 5: the innovativeness of a venture's business idea influences (a) the approach of founders toward committing themselves to venture creation, (b) the approach of founders toward hiring employees, and (c) engaging service providers during the venture creation.

\section{Methodology}

\subsection{The data: sample and operationalization}

To test the aforementioned propositions, we use a subset of the "Perfect Timing" (PT) database. Based on computer-assisted telephone interviews with founders, this dataset was collected between 2012 and 2016 by an international research team located in Utrecht (The Netherlands), New York (US), Germany (Düsseldorf and Cologne), London (UK), and Palermo (Italy). In order to capture possible variations in venture processes, the population chosen includes ventures of all legal forms (excluding sole proprietorship) that were registered between 2005 and 2011 in the information technology (IT) and alternative energy (AE) industries in Germany, and the USA. Out of this population, founders were randomly selected and invited to participate in an interview about the venture creation process of their company until a representative sample of 344 cases had been obtained.

The data's explicit focus on the timing and sequencing of venture creation activities enables us to study patterns in TFPs. Importantly, the dataset is restricted to the duration of the team formation process of each venture included. More concretely, this time span starts with the first time a founder, employee, or service provider actively worked on venture creation and ends with the moment in which the venture in question generated sustainable profits (defined as three consecutive profitable months). If a new venture never made sustainable profits, three alternative TFP ends can occur, namely the acquisition, merger, or liquidation of the respective venture. Had none of these events occurred, a TFP is categorized as ongoing until a maximum duration of 84 months. With regard to the team formation activities undertaken during the venture creation process, the dataset reports when each founder, employee, and external service provider started and, if applicable, stopped working for the new venture on a full-time or part-time basis.

To identify typologies of TFPs (dependent variable), we measure each venture's team formation activities by determining how many founders, employees, and service providers are involved at each month of the venture creation process. To this end, we first calculate the amount of time, expressed in full-time equivalents (FTE), invested in venture creation by each of the venture's founders. Second, we calculate the extent of employees hired (in FTEs) and, third, the number of service providers carrying out tasks for the new venture. For both the founder and employee dimension, we account for full-time as well as part-time arrangements (recorded as 0.5 FTE involvement). Our dataset thus records the extent of founder and employee involvement in increments of 0.5 from 0 to 5 FTE. For service providers, we record the number of service providers, because part-time arrangements are difficult to measure for external labor.

Given that venture creation processes were recorded on a monthly basis, we considered only the first five founders, employees, and service providers contributing to venture creation, so that 5.0 FTE also captures labor involvement of more than 5.0 FTE. As such, the dimensions reporting founder and employee involvement each have 11 states (ranging from 0 FTE to 5.0 FTE), while they have 6 states for contributions of service providers (ranging from 0 to 5 service providers). Table 1 provides an example of how these team formation activities are reported for a venture that achieved profitability after 11 months.

We report the team formation activities for each of the 344 ventures included in our database. Table 2 provides some descriptive statistics of the TFPs of all ventures analyzed, whereby the average TFP in the sample has a duration of 32.6 months. As Table 2 
Table 1 Example of team formation process

\begin{tabular}{|c|c|c|c|c|c|c|c|c|c|c|c|}
\hline \multirow[t]{2}{*}{ Dimension (in FTE) } & \multicolumn{11}{|c|}{ Month } \\
\hline & 1 & 2 & 3 & 4 & 5 & 6 & 7 & 8 & 9 & 10 & 11 \\
\hline Founder & 0.5 & 0.5 & 2 & 2 & 2 & 2 & 4 & 4 & 4 & 4 & 4 \\
\hline Employee & 0 & 0 & 0 & 0.5 & 0.5 & 1.5 & 1.5 & 1.5 & 1.5 & 1.5 & 1.5 \\
\hline Service provider & 1 & 1 & 0 & 0 & 0 & 0 & 0 & 1 & 2 & 2 & 2 \\
\hline
\end{tabular}

shows, venture teams are often small as the most common state for both the employee $(67.1 \%)$ and service provider $(46.1 \%)$ dimension is the involvement of 0 team members. For the founder dimension, the involvement of one founder at 1 FTE $(33.4 \%)$ is the most frequent state. The average founder involvement throughout the TFP is 1.5 FTE, in contrast to the much lower levels of employee involvement (.72 FTE) and service provider contribution (.95 SP).

We measure the different contextual factors (independent variables) that may influence which TFP is pursued by a new venture as follows. In order to measure the impact of labor market rigidity or, respectively, flexibility, we follow the standard approach of the Varieties-ofCapitalism literature which takes a country as a pars pro toto for its institutional environment (Hall and Soskice 2001b). In doing so, Germany is considered to be the most typical example of regulated labor-market institutions (Estévez-Abe and Iversen 2001), while the USA are considered to be the most typical example of labor market flexibility. Accordingly, we measure the flexibility of labor-market institutions by the country in which a venture is located, coding Germany as " 0 " (limited labor-market flexibility) and the USA as " 1 " (indicating flexible labor-market institutions).

The innovativeness of a venture's business idea was determined in a three-step process. In the first step, the founder was asked whether his business develops a radically new, incrementally new, or imitative product or service. ${ }^{1}$ In a second step, the interviewer (upon completion of the interview) cross-checked the founder's answer by comparing the venture's innovativeness with the innovativeness of the other ventures about which s/he had conducted interviews. In a third step, the person cleaning the data, again, cross-checked the degree of innovativeness indicated against the

\footnotetext{
${ }^{1}$ Concrete question asked in the questionnaire: "How would you describe the degree of novelty of your venture's core business idea?"
}

classification scheme he had developed while cleaning the data. In both step 2 and step 3, the interviewer and the data cleaner relied on the information provided by the founder as well as on online information about the venture's business idea. This three-step process made it possible to minimize the over-estimation bias that typically occurs when founders self-report the level of their business' innovativeness. The degree of innovativeness was measured as imitation (0), improvement (1), or radical innovation (2).

The same three-step process was used to determine whether the new venture develops a product, a service, or a business idea that combines elements of product and service. Given that the number of ventures that only develop products is fairly limited $(22.4 \%)$, we code the nature of good developed as a dichotomous variable, distinguishing between pure service ventures (0) and those ventures that either offer products or services and products (1).

Furthermore, the following control variables are included: possible industry differences in TFPs are controlled for by assessing whether the venture is active in the ICT industry (0) or the alternative energy industry (1). Furthermore, we assess whether a venture started independently (0) or as a spin-off (1), and whether a venture was registered in a year of well-being $(0)$ or economic crisis (1).

Table 3 provides some descriptive statistics about the independent variables used in the logistic regression analyses below. Furthermore, we tested for multicollinearity, finding that not a single variance inflation factor exceeded the traditionally accepted value of 1.2 points, so that multicollinearity does not appear to be a problem.

\subsection{Analyses}

In line with our theoretical illustrations, we run three different types of analyses: (1) In a first step, we assess 
Table 2 Distribution of TFP states by dimension

\begin{tabular}{llll}
\hline $\begin{array}{l}\text { Number of team } \\
\text { members (in FTE) }\end{array}$ & Founder (\%) & Employees (\%) & $\begin{array}{l}\text { Service } \\
\text { provider }(\%)\end{array}$ \\
\hline 0 & 1.7 & 67.1 & 46.1 \\
0.5 & 15.8 & 4.0 & \\
1 & 33.4 & 10.0 & 26.7 \\
1.5 & 17.2 & 2.9 & \\
2 & 12.3 & 5.7 & 17.2 \\
2.5 & 7.9 & .9 & \\
3 & 7.3 & 3.1 & 6.6 \\
3.5 & 1.5 & .6 & \\
4 & 2.1 & 2.8 & 3.1 \\
4.5 & .1 & .1 & .4 \\
5 & .6 & 2.8 & 100 \\
Total & 100 & 100 & \\
\hline
\end{tabular}

whether a limited number of systematically different TFPs approaches exist to founder involvement, employee hiring, and service provider engagement (Propositions 1a-1c) and illustrate how they look like. To this end, we use optimal matching (OM) techniques combined with cluster analyses, whereby each of the three TFP channels (founder, employee, and service provider involvement) constitutes the respective unit of analysis. The OM algorithm measures the distance between processes. If subsequently paired with cluster analyses, such sequence analyses allow us to explore and interpret patterns in longitudinal data (Halpin 2010).
Thus far, OM has mostly been used in sociology to explore career patterns (Abbott and Hrycak 1990; Stovel and Bearman 1996; Blair-loy 1999; Pollock 2007; Biemann et al. 2012). Only recently, Gordon (2012) applied OM techniques to explore gestation activities in venture creation processes. Given that more wide-ranging developments and applications of $\mathrm{OM}$ algorithms only occurred after the year 2000, OM can still be considered a fairly young method. Nevertheless, a standard way of running sequence analyses, based on OM techniques, has crystallized, which we here follow (Biemann and Datta 2014). It includes four steps:

Step 1: Coding the data

The first step consists in reporting the team formation process of each venture on a monthly basis. More concretely, this means that a sequence of states needs to be created for each of the three dimensions (founder, employee, service provider involvement) of the TFP of each venture. As outlined above, this process can vary in length for each venture, because it reports the (founder, employee, service provider) state for each month of the venture's TFP - in FTE for founder and employee involvement and in absolute numbers for service providers (see Table 1).

Step 2: Define the substitution costs

In order to measure the distance between two TFP sequences, created in step 1 , a cost needs to be assigned

Table 3 Descriptive statistics of independent and control variables

\begin{tabular}{|c|c|c|c|c|c|c|c|c|c|}
\hline & & \multirow[b]{2}{*}{$N$} & \multirow[b]{2}{*}{ Mean } & \multirow[b]{2}{*}{ Std. Dev. } & \multicolumn{5}{|c|}{ Correlation coefficient } \\
\hline & & & & & 1 & 2 & 3 & 4 & 5 \\
\hline \multicolumn{10}{|c|}{ Control variables } \\
\hline 1 & Industry $^{\mathrm{a}}$ & 344 & .29 & .453 & & & & & \\
\hline 2 & Spin-off ${ }^{a}$ & 344 & .09 & .291 & -.071 & & & & \\
\hline 3 & Crisis $^{\mathrm{a}}$ & 344 & .41 & .493 & -.034 & -.023 & & & \\
\hline \multicolumn{10}{|c|}{ Independent variables } \\
\hline 4 & Labor market $^{\mathrm{a}}$ & 344 & .4 & .491 & $-.131 * *$ & $-.121 * *$ & .036 & & \\
\hline 5 & Innovativeness $^{\mathrm{b}}$ & 344 & .64 & .646 & $-.211 * * *$ & $.089^{*}$ & -.063 & .038 & \\
\hline 6 & Nature of good ${ }^{\mathrm{a}}$ & 344 & .49 & .501 & .078 & .064 & $-.114^{* *}$ & $-.245 * * *$ & $.239 * * *$ \\
\hline \multicolumn{10}{|c|}{$p$ values $* * *<.01 ; * *<.05 ; *<.1$} \\
\hline \multicolumn{10}{|c|}{${ }^{\text {a }}$ Pearson's $r$} \\
\hline \multicolumn{10}{|c|}{${ }^{\mathrm{b}}$ Spearman's rho } \\
\hline
\end{tabular}


for replacing one state by any other state with the aim of transforming one sequence into the other. These socalled substitution costs range from 0 to an arbitrary maximum (here, 2) and are often estimated on the basis of the frequency of transitions between two states within the entire dataset. In our case, the sequence states represent equally sized steps along a continuous scale. This allow us to calculate the substitution costs as a linear interpolation between the minimum substation cost for equal states (0) and the maximum substitution cost (2) for the most distant states, as given by the number of FTEs difference between the two states.

To provide an example: replacing the minimal employee involvement of 0 FTE with the maximum of 5.0 FTE would have a cost of 2. Reducing the distance between two states by 0.5 FTE decreases the costs of exchanging these states by 0.2 . Subsequently, would the costs of replacing 0 FTE with 4.5 FTE be 1.8, 0 FTE with 2.5 FTE be 1, and so forth.

\section{Step 3: Calculating sequence similarity}

Based on these substitution costs, we then calculate (for each of the 344 sequences in our dataset) how costly it is to transform 1 sequence into any of the other 343 sequences. We do this for the founder, employee, and service provider dimension separately. The cost of transforming one sequence into the other expresses their respective distance. To calculate the distance of sequences that differ in length, we calculate their distance based on the length of the shorter of the two sequences. This reflects that the shorter of the two TFPs is unknown beyond the period observed and should thus not influence the difference measure. This novel solution addresses an often voiced concern of using OM for analyzing sequences in social science that vary greatly in length (Aisenbrey and Fasang 2010).

Furthermore, we normalize the respective values of sequence difference by dividing them by the length of the shorter of the two sequences in order to maintain a comparable difference measure across sequence pairs. This results in three matrices (one for founder, employee, and service provider involvement respectively) which report the distances between each sequence pair.

To provide an example, consider two team formation processes, where the hiring of employees evolves as a 4month process, namely (in FTE) 1-1-2-2, in the first venture and as a 3-month process 1-3-3 in the second venture. When we calculate their difference, we restrict the calculation to the number of months observed in the shorter of the sequences, in this case the first 3 months. Given that the states of the first period are identical, namely 1 FTE employee, their distance is zero. The states of the respective second period are 2 FTE apart, resulting in a transformation cost of 0.8 to equate the states (as reminder to the reader, the transformation costs are 0.2 for every $0.5 \mathrm{FTE}$; in this case, $4 * 0.2=0.8$ ). Given that the difference in the third period is only 1 FTE, the costs of equating these states is 0.4. In total, this amounts to transformation costs of $0+0.8+0.4=$ 1.2 points. If we then normalize these costs via the length of the shorter of the two compared sequences, $1.2 / 3=0.4$, we obtain the normalized costs of turning one sequence into the other, hence the distance of this pair of sequences.

Step 4: Perform a cluster analysis

In the concluding step, we cluster the founder, employee, and service provider dimensions of TFPs on the basis of their respective similarities. Consequently, all clusters obtained for each dimension encompass those processes that are particularly similar to each other, and distant to the processes of other clusters. Consequently, each cluster represents a distinct approach to founder, employee, or service provider involvement during TFPs.

We use a combination of various partition quality measurements, namely the weighted average silhouette width (ASWw), $R^{2}$, point biserial correlation (PBC), and Hubert's C (HC) to determine the optimal clustering solution among solutions which contain between 1 and 20 clusters. These measures indicate how similar sequences are within one cluster and how different they are between clusters. Consequently, we calculated these indicators for 1 , 2 , 3, etc., up to 20 clusters in order to determine their goodness of fit. In this way, we could determine for which cluster number the goodness of fit was maximized. In doing so, we also excluded cluster solutions which either did not yield distinct approaches because they clustered together too different sequences or spread out sequences over too many similar clusters.

In the second step, we run correlation analyses in order to understand whether there are systematic relationships between the extents to which founders, 
internal labor (employees), and external labor (service providers) are involved in venture creation (Propositions $2 \mathrm{a}-2 \mathrm{c})$. We do so based on the likelihood of a venture ending up in a particular cluster pair across two channels. Since the expected cell count in the contingency tables is low $(<5)$ for a large number of clustercombinations ( $56 \%$ of the cells), we use Fisher's exact test to examine the statistical significance of our results.

In the third step, we use one-versus-rest logistic regression models to identify the conditions that influence the team formation approaches taken toward founder, employee, and service provider involvement (dependent variable) during the TFP. Testing Propositions $3 a-5 c$, we determine the explanatory power of labor market flexibility, the innovativeness, as well as the nature of the good developed by the new venture (independent variables), whereby we control for the venture's industry, year of registration, and status as an independent or spin-off venture (control variables).

We fit the following model for each cluster to obtain the estimates:

$$
\begin{aligned}
\ln \left(\frac{p_{i}}{1-p_{i}}\right)= & \beta_{0}+\beta_{1} \text { Labor market }_{i} \\
& +\beta_{2} \text { Innovativeness }_{i} \\
& +\beta_{3} \text { Nature of } \operatorname{goods}_{i}+\beta^{\prime} x_{i}
\end{aligned}
$$

where $p_{i}$ denotes the probability that venture $i$ belongs to the cluster rather than to any of the other clusters; $\beta_{0}$ the cluster's intercept; $\beta_{1}, \beta_{2}$, and $\beta_{3}$ the estimated coefficients for our independent variables; $\beta$ a vector of coefficients for the control variables; and $x_{i}$ a vector of control variables.

\section{Results}

\subsection{Patterns in team formation processes}

The partition quality measurements identify the solution of seven clusters (out of the overall 1-20 solutions considered) as optimal for different approaches of founder involvement in venture creation $(\mathrm{ASWw}=0.46$; $R^{2}=0.68 ; \mathrm{PBC}=0.44 ; \mathrm{HC}=0.06$ ). Given that any of these seven clusters reveals a distinct approach to founder commitment to venture creation, we find support for Proposition 1a (Fig. 2).
The 7 clusters we identify are fairly homogenous in size with two exceptions: the second founder cluster (F2) is the largest cluster, including 108 ventures. In turn, cluster F7 (large founder team) is smallest $(n=13)$, while the remaining clusters contain between 37 and 54 ventures.

F1 is the third largest cluster $(n=49)$ and features ventures with a single part-time founder. Hence, for most of the TFP, founder involvement is $0.5 \mathrm{FTE}$ in this cluster. While a minority of ventures goes through intermittent periods of inactivity or an increase to 1 founder FTE, this is a largely static approach. F2 (full-time founder) and F3 (small founder team) exhibit similarly static processes in which the founders invested 1 FTE, respectively $1.5 \mathrm{FTE}$ for much of the process, with a few exceptions scaling up or down toward the end of the process. Ventures grouped together in F7 (large founder team) do not display a clear transition pattern either, but start out with larger founder team (3 FTE) than those in any other cluster.

The three other approaches taken to founder involvement are more dynamic. Accordingly, cluster F6 (late and limited team growth) consists of ventures that start out with a mid-sized team of 2 or 2.5 FTE. Most ventures, especially those with longer TFPs, subsequently increase the founder involvement to up to 4 FTE. The sequences is F4 (early growth solo founder to founder team) and F5 (early and constant team growth) are characterized by clear transition patterns. Accordingly, ventures in F4 begin the process with a founder involvement of 0.5 FTE and subsequently scale up to 1 or more founders around 9 months. Their counterparts in F5 begin at 1 FTE, before choosing to increase founder commitment after about 7 months, eventually settling on 2 to 3 FTE of founder involvement.

With regard to the clustering of the approaches taken toward employee hiring, the partition quality measurements indicate that a 6-cluster solution (out of the 1-20 cluster solutions considered) is best $(\mathrm{ASWW}=0.64$; $\left.R^{2}=0.63 ; \mathrm{PBC}=0.55 ; \mathrm{HC}=0.06\right)$. Given that each of these six clusters represents a distinct approach toward employee hiring throughout the venture creation process, we find empirical support for Proposition $1 \mathrm{~b}$ (Fig. 3).

The distribution over the six approaches found for employee hiring is heavily skewed and less homogenous than that of the founder dimension. By far the largest group of ventures $(n=226)$ is found in employee 


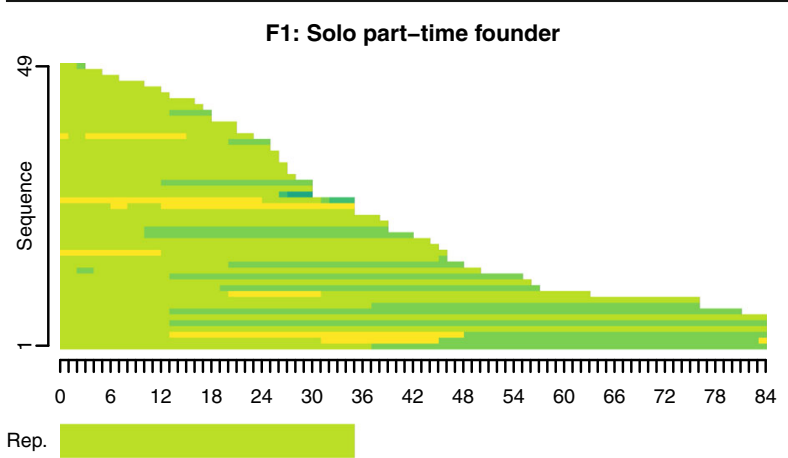

\section{F3: Small founder team}

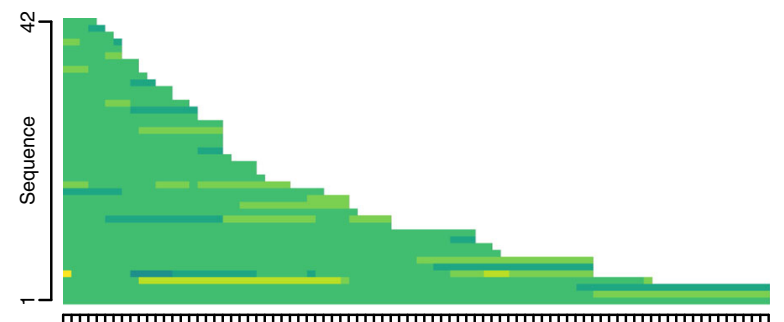

$\begin{array}{lllllllllllllll}0 & 6 & 12 & 18 & 24 & 30 & 36 & 42 & 48 & 54 & 60 & 66 & 72 & 78 & 84\end{array}$

Rep.

F5: Early and constant team growth

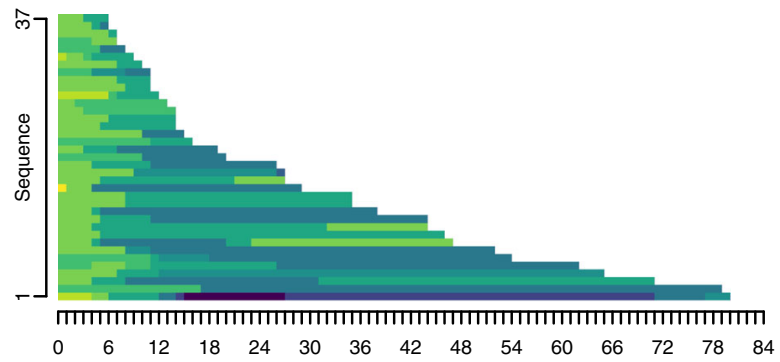

Rep.

F7: Large founder team

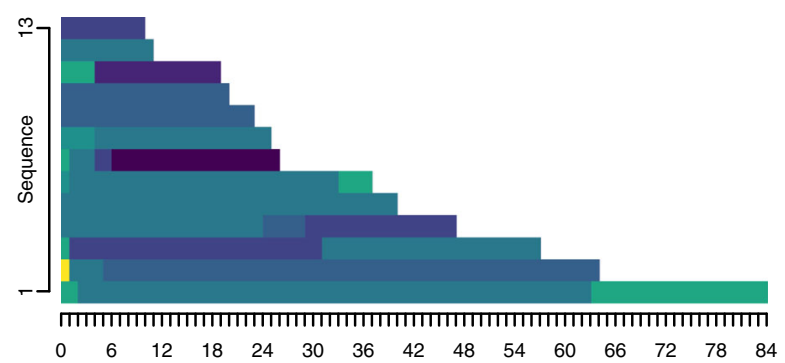

Rep.

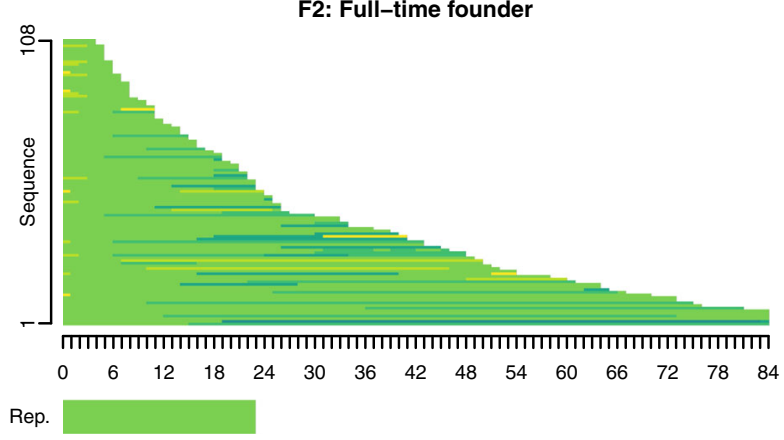

F4: Early growth solo founder to founder team

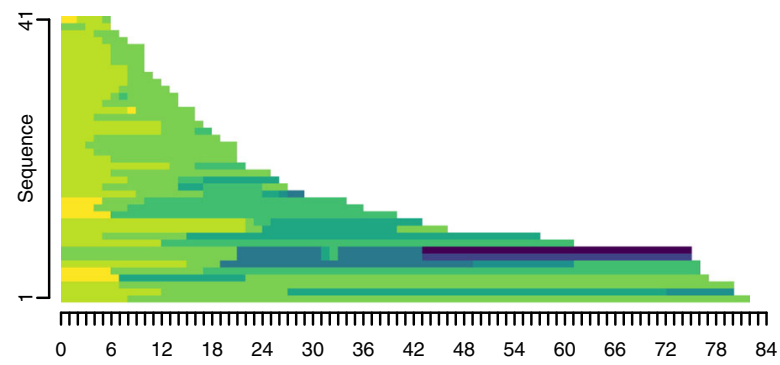

Rep.

F6: Late and limited team growth

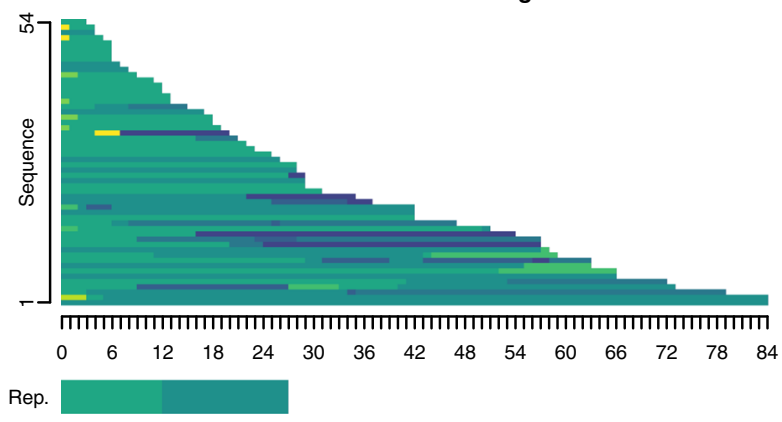

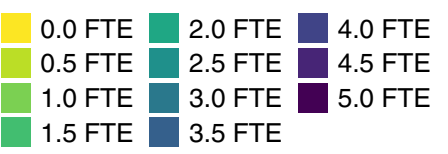

Fig. 2 Distinct approaches to founder involvement. Rep. is a representative summary of the cluster based on the median length and states of its sequences 


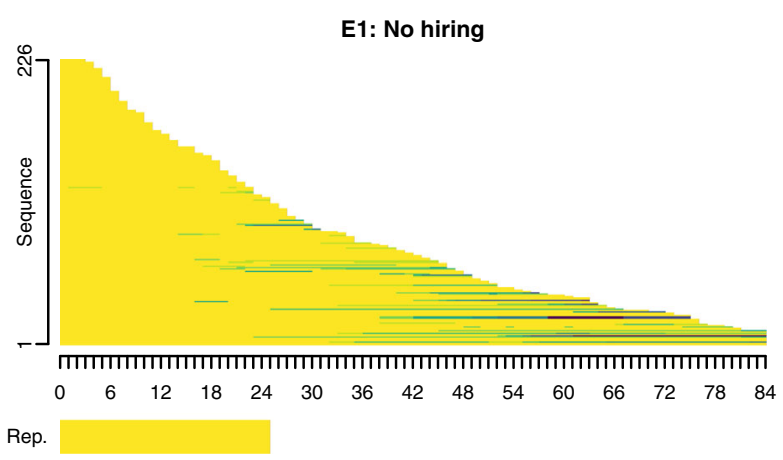

E3: Early and limited hiring

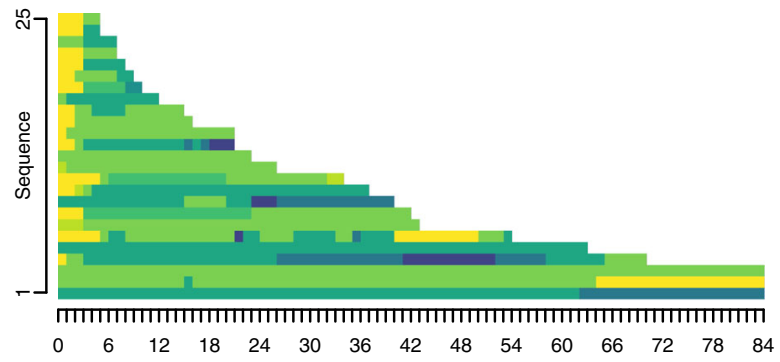

Rep.

E5: Early and extensive hiring

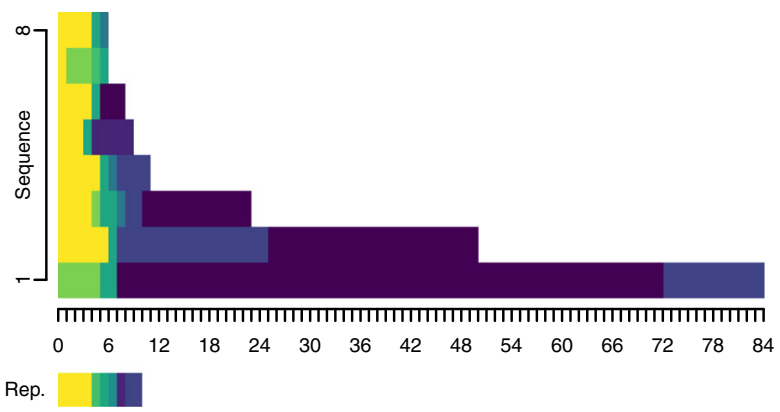

E2: Late and limited hiring

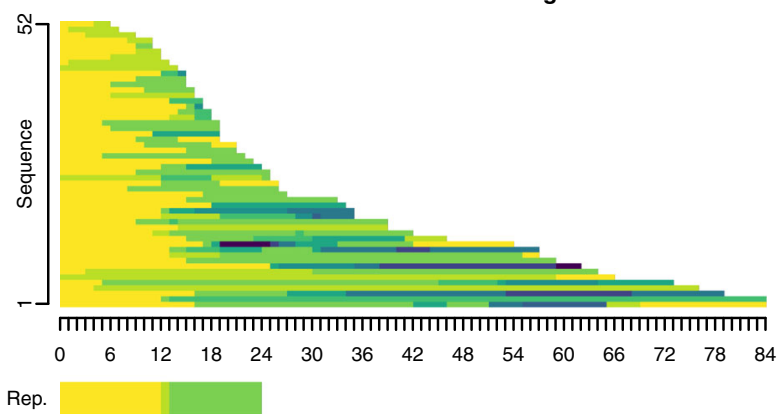

E4: Late and extensive hiring

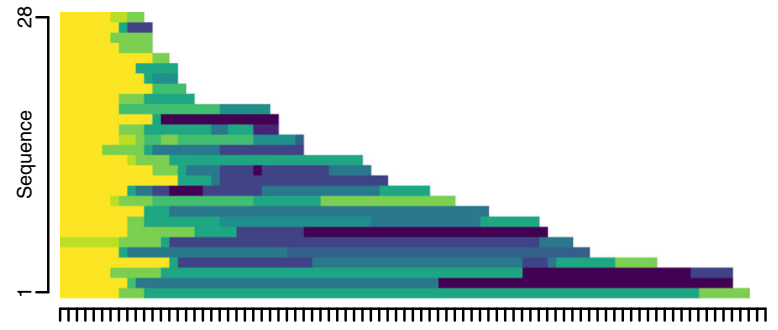

Rep.

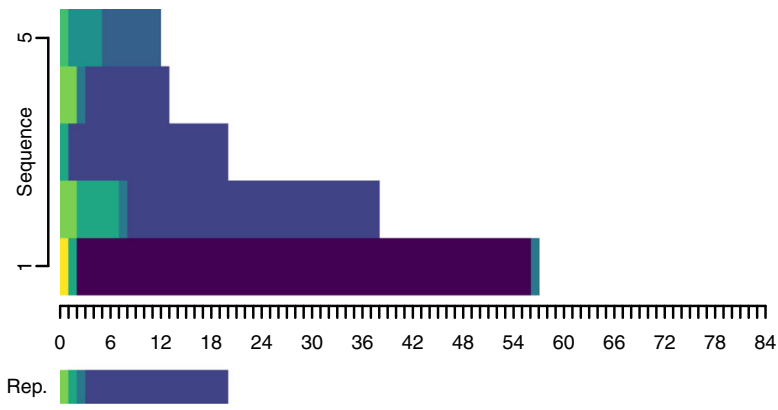

Fig. 3 Distinct approaches to employee hiring. Rep. is a representative summary of the cluster based on the median length and states of its sequences

cluster E1, a cluster characterized by the absence of employees. Compared to this passive and static approach to hiring employees, the rest of the clusters are more dynamic and are characterized by transition patterns and different levels of employee hiring. They range from 5 to 52 ventures in size.

E3 (early and limited hiring) and E5 (early and extensive hiring) both depict an approach in which the venture begins without an employee but then starts hiring within the first 6 months of the TFP. The major difference between these two approaches consists in the extent of hiring. Whereas ventures following the "early and extensive hiring" approach (E5) hire up to 5 FTE, their counterparts following the "early and limited hiring" approach (E3) transition from no employee to 1 or 2 FTE after 6 months. Similarly, dynamic transitions can be observed in E4 and E2. While the transition from no to 2-3 FTE in the "late and extensive hiring" approach (E4) happens after about 9 months, ventures following the "late and limited hiring" approach (E2) 
hire to a lesser extent (around 1 FTE) and do so mostly 12 months into the TFP or even later.

Furthermore, E2 and E3 both depict an approach in which ventures begin without an employee but eventually hire employees to the capacity of 1 FTE. The difference between these two approaches is the timing of the transition. In ventures pursuing the "early and limited hiring" approach (E3), this transition takes place within the first 6 months, while this typically takes more than 12 months for ventures following the "late and limited hiring" approach (E2). We observe a much stronger and more immediate employee involvement among ventures following the "immediate and extensive hiring" approach (E6). While only few
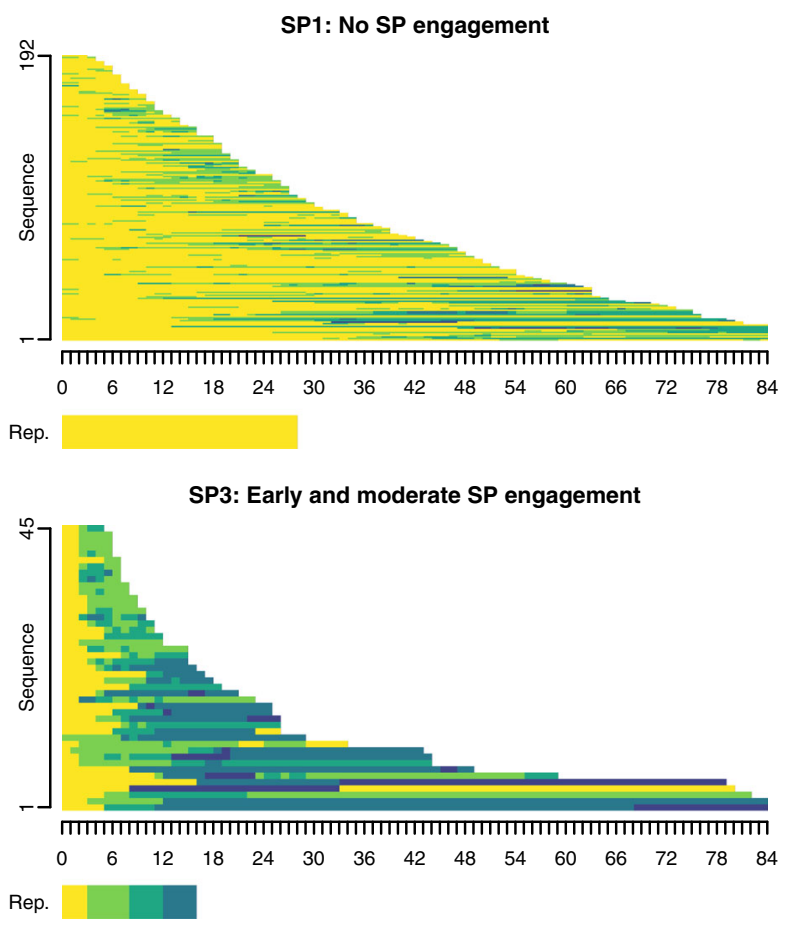

SP5: Immediate and extensive engagement

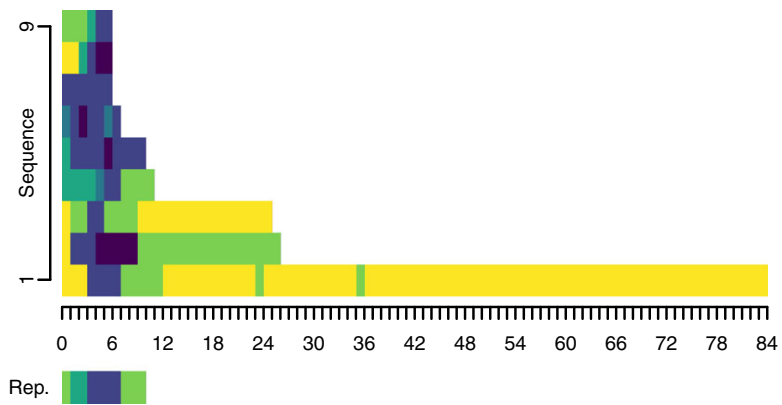

Fig. 4 Distinct approaches to service provider engagement. Rep. is a representative summary of the cluster based on the median length and states of its sequences ventures $(n=5)$ fall in this cluster, it is the most expansive approach as ventures start with 1-2 FTE employees and quickly expand to up to 5 FTE employees.

Regarding possible approaches taken toward engaging service providers, the partition quality measurements identify the 5 cluster solution (out of the overall $1-20$ solutions considered) as optimal $(\mathrm{ASWw}=0.43$; $\left.R^{2}=0.48 ; \mathrm{PBC}=0.57: \mathrm{HC}=0.08\right)$. Given that these results indicate that five distinct approach toward engaging service providers exist, this lends empirical support for Proposition 1c (Fig.4).

The five clusters identified in the service provider dimension are similarly heterogeneous in size as those

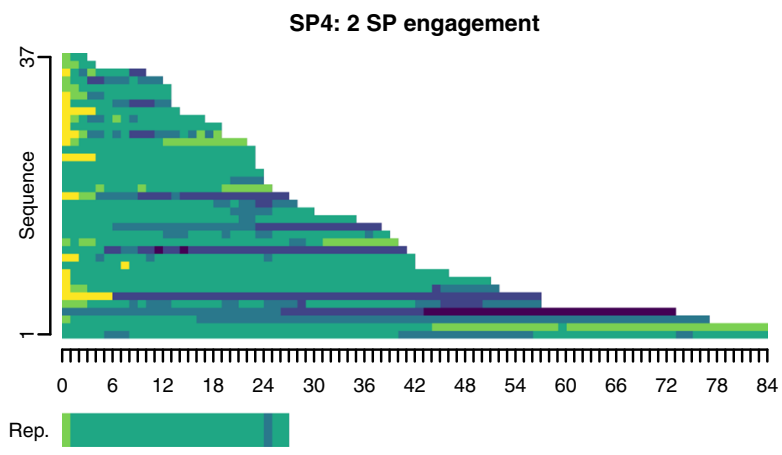

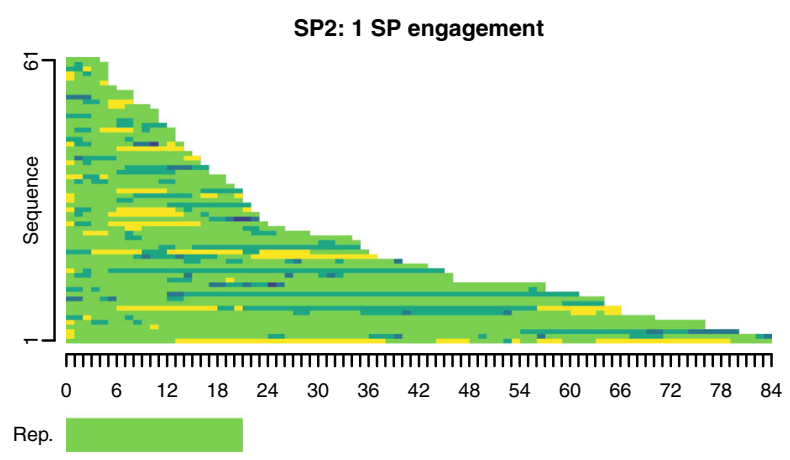

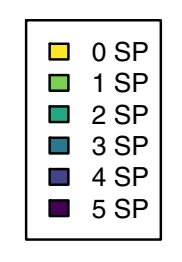

states of its sequences

Springer 
of the employee dimension. In parallel to the employee dimension, the largest cluster (SP1) is dominated by inactivity. With a size of 192 ventures, it is more than 3 times as big as the second largest cluster SP2 $(n=61)$.

In contrast to SP1, SP2 (one SP engagement) features ventures that typically involve one service provider. These ventures hire one service provider early on and sustain or repeat collaboration with this service provider for the remainder of TFP. Ventures in cluster SP4 (two SP engagement) typically rely on two service providers. In most cases, these service providers were engaged immediately at the start of the TFP. While some ventures eventually hire more than two service providers, the cluster contains mostly static sequences. In SP3 (early and moderate SP engagement), we find ventures that rely similarly heavily on external service providers, but mostly started hiring them after about 6 months into the TFP. The last cluster, SP5 (immediate and extensive SP engagement), is small, and is characterized by immediate and intense collaboration with external providers. However, this collaboration is very brief, either because the venture creation is quickly completed or because service providers are not retained for the remainder of the TFP.

4.2 Correlations between founder, employee, and service provider involvement

In line with Proposition 2b, Fisher's exact test reveals that there is no significant correlation between the approaches taken toward founder and service provider involvement (Table 4). Overall, we also find support for Propositions $2 \mathrm{a}$ and $2 \mathrm{c}$ as we find statistically significant correlations between the approaches toward founder and employee involvement on the one hand, and employee and service provider engagement on the other hand. However, the low Cramer's $V$ values (.19 and .15 respectively) indicate that the observed correlations are comparatively weak. To better understand these correlations, we investigate the links between

Table 4 Correlation between TFP dimension

\begin{tabular}{lll}
\hline Dimensions & Fisher's exact test & Cramer's $V$ \\
\hline Founder $\times$ Employee & $50,684 * * *$ & .194 \\
Founder $\times$ Service provider & 27,125 & .137 \\
Employee $\times$ Service provider & $26,685 *$ & .149 \\
\hline$p$ values $* * *<.01 ; * *<.05 ; *<.1$ &
\end{tabular}

founder and employee involvement (Table 5) and employee and service provider engagement (Table 6) with the help of pairwise cross-tabulations.

The cross-tabulations of the cluster pairs of the founder and employee dimension demonstrate that the observed correlations stem from a limited number of cluster pairs that co-occur particularly often (Table 5). In line with Proposition 2a, these reveal additive effects between the involvement of founders and the hiring of employees. Accordingly, E1 including ventures which never hire an employee frequently co-occur with parttime entrepreneurship throughout the venture creation process (F1). In contrast, ventures growing to larger founder teams over time (F5) are under-represented in said E1, indicating that founder teams committing substantial amounts of their own time are rare in ventures that abstain from hiring. The combination of F3 (small founder team) and E2 (late and limited hiring) co-occurs particularly often and is indicative of a slow growth process driven by a single full-time founder or a duo of two part-time founders. Another indication of additionality between founder involvement and employee hiring is that ventures in the two transition clusters F4 (early growth solo founder to founder team) and F5 (early and constant team growth) are associated with the transition cluster E4 (late and extensive hiring). We thus conclude that Proposition $2 \mathrm{a}$ is empirically supported.

With regard to employee hiring and service provider engagement, we find substitute effects (Table 6). Accordingly, "late and limited hiring" approaches (E2) hardly co-occur with not hiring any service providers (SP1), but are more likely to co-occur with "early and moderate SP engagement" (SP3). Ventures hiring multiple employees at a comparatively late stage (E4) tend to make early and continuous use of one external service provider (SP2).

While the majority of combinations between employee hiring and service provider engagement seem to be independent of each other, we see that employee hiring and service provider engagement is substitute in those instances where they co-occur. This, in turn, lends empirical support to Proposition 2c.

\subsection{Determinants of approaches toward founder, employee, and service provider involvement}

Having found systematically different approaches to founder, employee, and service provider involvement 
Table 5 Overlap between founder and employee clusters

\begin{tabular}{lllllll}
\hline Founder cluster & \multicolumn{6}{l}{ Employee cluster } \\
\cline { 2 - 7 } & E1 (\%) & E2 $(\%)$ & E3 $(\%)$ & E4 $(\%)$ & E5 (\%) & E6 (\%) \\
\hline F1 & 79.6 & 18.4 & a & a & a & a \\
F2 & 65.7 & 11.1 & 13.9 & 5.6 & a & a \\
F3 & 57.1 & 26.2 & a & a & a & a \\
F4 & 68.3 & 9.8 & a & 14.6 & a & a \\
F5 & 51.4 & 16.2 & a & 21.6 & a & a \\
F6 & 70.4 & 18.5 & a & a & a & a \\
F7 & 53.8 & a & a & a & a & a \\
Column total & 65.7 & 15.1 & $7.3 \%$ & 8.1 & 2.3 & 1.5 \\
\hline
\end{tabular}

Values indicate percentage of the row cluster that is in the column cluster

${ }^{\mathrm{a}}=<5$ expected observations
The only other founder approach that is significantly associated with several structural factors is the transition process from 1 FTE to 2 or more FTE (F5). Founders pursuing this approach are much more likely to work for incrementally innovative, but not for radically innovative ventures (F5; Exp $\beta=3.014 ; p<.1$ ), lending only partial support to Proposition 5a. Yet, in line with our reasoning of Proposition $3 \mathrm{a}$, founders transitioning from low to higher time commitments are roughly three times more likely to be found in regulated rather than deregulated labor markets (F5; Exp $\beta=.352 ; p<.05$ ). Finally, founders in cluster F5 (early and constant team growth) are also more likely to be active in ICT rather than alternative energy industries.

With regard to the drivers of the approach chosen toward employee hiring (Table 8), it is first interesting, and rather unsurprising, to note that the hiring of no employees (E1) occurs less frequently in incrementally innovative ventures (E1; $\operatorname{Exp} \beta=.646, p<.1)$. This, in turn, lends support to the reasoning of Proposition $5 \mathrm{~b}$. Also spin-offs are markedly less likely not to hire any employees (E1; Exp $\beta=.386 ; p<.05)$, but twice as likely to hire at least one employee about 12 months after the start of venture creation (E2; Exp $\beta=$ $2.14 ; p<.1)$. Furthermore, alternative energy ventures are significantly more likely to hire at least one employee 12 months after venture begins (E2; $\operatorname{Exp} \beta=$ $2.517 ; p<.05)$. This might be explained by the long time it takes to obtain all required permits, which implies that employees in alternative energy ventures are hired relatively late in the TFP.

As suggested by the reasoning underlying Proposition $4 \mathrm{~b}$, ventures developing products require more resources and need longer time to assemble these resources. The finding that product developers tend to hire rather "late

\footnotetext{
${ }^{2}$ Given that the $R^{2}$ s of these four clusters are low, factors other than the external ones included - such as process-related measures (e.g., whether, or not, the venture acquired external finance) - may be more relevant explanators. Yet, in answer to the claims of Samuelsson and Davidsson (2009) and Gartner and Shaver (2012) to study the impact of contextual factors on venture creation, we here focus on the aforementioned models.
} 
Table 6 Overlap between employee and service provider clusters

\begin{tabular}{|c|c|c|c|c|c|}
\hline \multirow[b]{2}{*}{ Employee cluster } & \multicolumn{5}{|c|}{ Service provider cluster } \\
\hline & SP1 $(\%)$ & SP2 (\%) & SP3 $(\%)$ & SP4 (\%) & SP5 $(\%)$ \\
\hline E1 & 60.6 & 15.9 & 9.7 & 11.1 & 2.7 \\
\hline E2 & 44.2 & 21.2 & 21.2 & 11.5 & $\mathrm{a}$ \\
\hline E3 & 56 & a & a & a & a \\
\hline E4 & 50 & 25 & a & a & a \\
\hline E5 & a & a & a & a & a \\
\hline E6 & $\mathrm{a}$ & 20 & $\mathrm{a}$ & a & $\mathrm{a}$ \\
\hline Column total & 55.8 & 17.7 & 13.1 & 10.8 & 2.6 \\
\hline
\end{tabular}

and extensive" (E4) thus supports Proposition 4b (E4; $\operatorname{Exp} \beta=2.222 ; p<.1)$. Finally, we do not find any evidence in support of the idea, expressed in the reasoning of Proposition 3b, that regulated labor-market institutions hamper the hiring of employees.

Regarding the engagement of service providers (Table 9), we observe several significant conditions in which ventures are particularly likely not to engage any service providers (SP1). We find twice as many German as American ventures not to hire service providers (SP1; Exp $\beta=2.081 ; p<.05)$. As outlined in, and in support of, the theoretical illustrations leading to Proposition 3c, rigid labor-market institutions are thus likely to stimulate the use of external service providers. Furthermore, we find that product developing ventures are more likely not to hire service providers (SP1; Exp $\beta=1.617 ; p<.05)$. Given the literature's argument that product developers invest and scale up more than service developers, this finding - together with the above finding on employee hiring - can be interpreted to the extent that product developing ventures prefer the stability of hiring employees over the flexibility of engaging service providers. This supports Proposition $4 \mathrm{c}$ that the nature of the produced influences the approach to engaging service providers.

Interestingly, we observe the opposite associations with cluster SP3 (early and moderate SP engagement), which means that ventures in rigid labor markets (SP3; $\operatorname{Exp} \beta=.532 ; p<.1)$ as well as ventures developing services (SP3; $\operatorname{Exp} \beta=.495 ; p<.05)$ are twice as likely as their respective counterparts to substantially hire service providers about 6 months into the TFP. This lends

Table 7 Regression estimates for founder clusters

\begin{tabular}{|c|c|c|c|c|c|c|}
\hline \multirow[t]{2}{*}{ Variable } & \multicolumn{6}{|c|}{ Founder cluster $(\operatorname{Exp} \beta)$} \\
\hline & $\mathrm{F} 1$ & $\mathrm{~F} 2$ & F3 & $\mathrm{F} 4$ & F5 & F6 \\
\hline Nature of good & $1.895^{*}$ & .695 & .91 & .824 & 1.286 & .914 \\
\hline Innovativeness incremental & $.341 * *$ & .964 & .961 & .984 & $3.014 * *$ & 1.314 \\
\hline Innovativeness radical & $.293 * *$ & 1.75 & .736 & 1.5 & 1.447 & 1.199 \\
\hline Labor market & 1.518 & 1.223 & .775 & 1.197 & $.352 * *$ & .996 \\
\hline Industry & .594 & 1.449 & .95 & 1.579 & $.402 *$ & 1.393 \\
\hline Spin-off & .985 & .931 & 1.003 & 1.175 & 1.117 & .757 \\
\hline Crisis & 1.441 & .75 & 1.084 & .894 & .922 & 1.316 \\
\hline Intercept & $.165 * * *$ & $.487 * * *$ & $.165 * * *$ & $.118 * * *$ & $.094 * * *$ & $.139 * * *$ \\
\hline Observations in cluster & 49 & 108 & 42 & 41 & 37 & 54 \\
\hline Total observations & 344 & 344 & 344 & 344 & 344 & 344 \\
\hline$R^{2}$ & .073 & .031 & .005 & .015 & .128 & .012 \\
\hline
\end{tabular}

Cluster F7 not included, because number of cases too limited for meaningful regression results

$p$ values $* * *<.01 ; * *<.05 ; *<.1$ 
Table 8 Regression estimates for employee clusters

\begin{tabular}{|c|c|c|c|c|}
\hline \multicolumn{5}{|l|}{ Employee cluster $(\operatorname{Exp} \beta)$} \\
\hline Variable & E1 & E2 & E3 & E4 \\
\hline Nature of good & .881 & .963 & .482 & $2.222 *$ \\
\hline Innovativeness incremental & $.646^{*}$ & 1.506 & 1.107 & 1.371 \\
\hline Innovativeness radical & 1.160 & .443 & 1.772 & 1.059 \\
\hline Labor market & 1.255 & .698 & 1.156 & .948 \\
\hline Industry & .698 & $2.517 * *$ & 1.245 & .520 \\
\hline Spin-off & $.386 * *$ & $2.14 *$ & .412 & 1.428 \\
\hline Crisis & 1.318 & 1.177 & $.394 *$ & .854 \\
\hline Intercept & $2.486 * * *$ & $.111^{* * *}$ & $.122 * * *$ & $.057 * * *$ \\
\hline Observations in cluster & 226 & 52 & 25 & 28 \\
\hline Total observations & 344 & 344 & 344 & 344 \\
\hline$R^{2}$ & .063 & .075 & .057 & .052 \\
\hline
\end{tabular}

Clusters E5 and E6 not included, because number of cases too limited for meaningful regression results $p$ values $* * *<.01 ; * *<.05 ; *<.1$

additional support to the reasoning underlying Proposition 3c and Proposition 4c.

No support is found for the reasoning underlying Proposition 5c, which suggests that the innovativeness of a venture's business does not influence the extent of service provider engagement. However, we find evidence that ICT ventures are likely not to hire any service providers (SP1; Exp $\beta=.553 ; p<.05)$, but highly unlikely to intensely engage service provider (SP4; Exp $\beta=2.964 ; p<.05)$. We therefore conclude that, depending on their industry, ventures take significantly different approaches toward hiring service providers.

\section{Discussion and conclusions}

What have we learned about possible approaches to team formation during venture creation and their drivers? Most importantly, our analyses lend support to the underlying assumption of both the stage-based

Table 9 Regression estimates for service provider clusters

\begin{tabular}{lllll}
\hline Variable & \multicolumn{2}{l}{ Service provider cluster $(\operatorname{Exp} \beta)$} & & SP3 \\
\cline { 2 - 5 } & SP1 & SP2 & $.495^{* *}$ & SP4 \\
\hline Nature of good & $1.617^{* *}$ & .892 & 1.312 & 1.166 \\
Innovativeness incremental & .823 & 1.113 & 1.401 & 1.134 \\
Innovativeness radical & .653 & 1.531 & $.532^{*}$ & .952 \\
Labor market & $2.081^{* *}$ & .662 & 1.039 & .714 \\
Industry & $.553^{* *}$ & 1.343 & 1.133 & $2.964 * *$ \\
Spin-off & .952 & .795 & .659 & 1.300 \\
Crisis & 1.375 & .860 & $.255^{* * *}$ & .940 \\
Intercept & .893 & $.24 * * *$ & 45 & $.078^{* * *}$ \\
Observations in cluster & 192 & 61 & 344 & 37 \\
Total observations & 344 & 344 & .04 & 344 \\
$R^{2}$ & .073 & .018 & & .064 \\
\hline
\end{tabular}

Cluster SP5 not included, because number of cases too limited for meaningful regression results

$p$ values $* * *<.01 ; * *<.05 ; *<.1$ 
(Levie and Lichtenstein 2010) and the activity-based literatures (Liao et al. 2005; Gartner and Shaver 2012) that team formation processes are "order, not chaos." Yet, in contrast to the stage-based literature, we did not find one best way of organizing team formation during venture creation. Instead, we identified seven distinct ways in which founders contribute to venture creation (ranging from part-time entrepreneurship to strongly growing founder teams), six different approaches toward hiring employees (ranging from no hiring to the immediate hiring of numerous employees), and five distinct ways of engaging service providers (also ranging from the engagement of no service providers to a high number thereof). Most importantly, these approaches differ from each other in the extent to which they are static or, respectively, dynamic: while static approaches are characterized by a stable number of founders, employees, or service providers contributing to venture creation, their number varies throughout the venture creation process in dynamic clusters - whereby it is interesting to note that, with one exception, all dynamic approaches are characterized by an increase, rather than a decrease, in team size.

Interestingly, the approaches taken toward founder, employee, and service provider involvement during venture creation partly correlate with each other. In other words, the extent to which founders engage in venture creation on the one hand, and hire employees and service providers on the other hand, is partly correlated. With regard to founder and employee involvement, we observed additionality effects as previously described in the literature (Cooper et al. 1989; Reynolds and White 1997), meaning that founders who only engage part-time in venture creation often also abstain from hiring any employees. Similarly, ventures whose founder team grows slowly over the venture creation process also slowly increase their employee base by about one employee over time. The same holds for high-growth ventures that are characterized by both substantially growing founder and employee teams. Interestingly, such additionality effects could only be observed for internal labor resources, i.e., between founder and employee involvement. Systematic correlations between founder and service provider approaches could not be observed. Finally, and in line with (Román et al. 2011), we found some substitution effects in the extents to which employees and service providers are engaged in venture creation as ventures tend to rely on service providers in those moments where hardly any employees are hired, and vice-versa.
Finally, we showed that several structural conditions influence which approach is taken toward founder involvement, employee hiring, and service provider engagement. Accordingly, we saw that the nature of the good developed (product or service) often influences team formation approaches, while labor-market institutions and the innovativeness of a venture's business idea partly impacts on team formation processes: contrary to service developers, product developing ventures are characterized by part-time founders, the late but intense hiring of employees, and the early and intense hiring of service providers (see Audretsch et al. 2004; Fritsch and Weyh 2006). Furthermore, the team formation processes of incrementally innovative ventures are hardly characterized by part-time founders but rather by slowly increasing founder teams and the systematic hiring of employees. Finally, rigid labor-market institutions imply that ventures grow their founder team rather slowly, do not impact the approach taken toward employees hiring, but make that ventures substantially rely on external service providers to get the work done. Overall, and in line with the VoC literature (see Hall and Soskice 2001b), our results thus suggest that institutional labormarket rigidity leads to small-scale growth.

Furthermore, our paper also offers important methodological contributions. By applying optimal matching techniques to analyze venture creation processes, we illustrate how this novel methodological approach can be used in business and management research. Our research thus offers a methodological answer to the long-standing call for systematic insights into how venture creation processes unfold over time (Van de Ven and Engleman 2004; Ruef 2005; Moroz and Hindle 2012). In addition, we developed a new way to determine the distances between sequences of highly different lengths, a problem that is frequently occurring in social processes (Aisenbrey and Fasang 2010). We hope that our methodological advancements can contribute to, a much needed, better understanding of longitudinal data in the context of venture creation.

Like virtually all research, our study has its limitations, which pave the way for future research. To better assess the impact of different labor-market institutions, a broader database including data for more than two countries would be highly useful. Besides broadening the existing database, future research should also focus on other drivers of team formation than the ones we considered. This is particularly true as the low $R^{2}$-values of our regression analyses indicate that other factors than the 
ones included exist that have a significant influence on a venture's team formation approach. These factors might also include internal and time-dependent characteristics of ventures, such as the funding acquisition process of a venture. Finally, future studies would also provide novel and highly appreciated insights if they could link team formation processes to specific outcomes, such as venture success.

With our exploration of team formation processes, we have investigated a part of venture creation that has mostly been a black box in the past. While previous research has chiefly studied the link between venture characteristics and the outcomes of venture creation, namely growth and success, we here provide a detailed account of how team formation plays out between the starting and end point of venture creation. By uncovering that distinct team formation processes exist, and what they look like, we have been able to discern differences in venture creation that have, to date, been largely ignored.

Acknowledgements This project has received funding from the European Union's Horizon 2020 research and innovation programme under grant agreement No 649378. This paper reflects only the author's view and the agency is not responsible for any use that may be made of the information it contains. Furthermore, we wish to thank the members of the H2020 project FIRES for their thoughtful comments on this paper in particular Koen Frenken, Johannes van Biesebroeck, Alina Sorgner, Mark Sanders, and Claire Economidou, as well as the two anonymous reviewers.

Open Access This article is distributed under the terms of the Creative Commons Attribution 4.0 International License (http:// creativecommons.org/licenses/by/4.0/), which permits unrestricted use, distribution, and reproduction in any medium, provided you give appropriate credit to the original author(s) and the source, provide a link to the Creative Commons license, and indicate if changes were made.

\section{References}

Abbott, A., \& Hrycak, A. (1990). Measuring resemblance in sequence data: an optimal matching analysis of musicians' careers. American Journal of Sociology, 96(1), 144-185. https://doi.org/10.1086/229495

Abernathy, W. J., \& Clark, K. B. (1985). Innovation: mapping the winds of creative destruction. Research Policy, 14(1), 3-22. https://doi.org/10.1016/0048-7333(85)90021-6

Aisenbrey, S., \& Fasang, A. E. (2010). New life for old ideas: the second wave of sequence analysis bringing the course back into the life course. Sociological Methods \& Research, 38(3), 420-462. https://doi.org/10.1177/0049124109357532
Aldrich, H. E. (2001). Who wants to be an evolutionary theorist? Remarks on the occasion of the year 2000 OMT distinguished scholarly career award presentation. Journal of Management Inquiry, 10(2), 115-127. https://doi. org/10.1177/1056492601102004

Amason, A. C., Shrader, R. C., \& Tompson, G. H. (2006). Newness and novelty: relating top management team composition to new venture performance. Journal of Business Venturing, 21(1), 125-148. https://doi.org/10.1016/j. jbusvent.2005.04.008

Andries, P., \& Czarnitzki, D. (2014). Small firm innovation performance and employee involvement. Small Business Economics, 43(1), 21-38. https://doi.org/10.1007/s11187014-9577-1

Audretsch, D. B., Klomp, L., Santarelli, E., \& Thurik, A. R. (2004). Gibrat's law: are the services different? Review of Industrial Organization, 24(3), 301-324. https://doi. org/10.1023/B:REIO.0000038273.50622.ec

Bates, T. (1990). Entrepreneur human capital inputs and small business longevity. The Review of Economics and Statistics, 72(4), 551. https://doi.org/10.2307/2109594

Baughn, C. C., Sugheir, J., \& Neupert, K. E. (2010). Labor flexibility and the prevalence of high-growth entrepreneurial activity. Journal of Small Business and Entrepreneurship, 1(1), 115. https://doi.org/10.1080/08276331.2010.10593470

Becker, G. S. (1962). Investment in human capital: a theoretical analysis. Journal of Political Economy, 70(No. 5 (Part2)), 949. https://doi.org/10.1086/258724.

Bennett, R. J., Robson, P. J. A., Ober, R., Be Nn, T. J., Tt, E., \& Obson, L. J. A. R. (1999). The use of external business advice by SMEs in Britain. Entrepreneurship \& Regional Development, 11(2), 155-180. https://doi.org/10.1080 /089856299283245

Biemann, T., \& Datta, D. K. (2014). Analyzing sequence data: optimal matching in management research. Organizational Research Methods, 17(1), 51-76. https://doi.org/10.1177 /1094428113499408

Biemann, T., Zacher, H., \& Feldman, D. C. (2012). Career patterns: a twenty-year panel study. Journal of Vocational Behavior, 81(2), 159-170. https://doi.org/10.1016/j.jvb.2012.06.003

Blair-loy, M. (1999). Career patterns of executive women in finance: an optimal matching analysis. American Journal of Sociology, 104(5), 1346-1397. https://doi.org/10.1086/210177

Block, J. H., \& Landgraf, A. (2016). Transition from part-time entrepreneurship to full-time entrepreneurship: the role of financial and non-financial motives. International Entrepreneurship and Management Journal, 12(1), 259282. https://doi.org/10.1007/s11365-014-0331-6

Bornhäll, A., Daunfeldt, S.-O., \& Rudholm, N. (2016). Employment protection legislation and firm growth: evidence from a natural experiment. Industrial and Corporate Change, 25(3), 1-17. https://doi.org/10.1093/icc/dtw017

Bosma, N., \& Levie, J. (2009). Global entrepreneurship monitor 2009 Executive Report. Global Entrepreneurship Research Association.

Bosma, N., Van Praag, M., Thurik, R., \& De Wit, G. (2004). The value of human and social capital investments for the business performance of startups. Small Business Economics, 23(3), 227-236. https://doi. org/10.1023/B:SBEJ.0000032032.21192.72 
Buddensiek, M., Piorkowsky, M.-B., \& Herter-Eschweiler, R. (2013). Selbstständige in Deutschland 1992-2011. Bonn.

Cardon, M. S., \& Stevens, C. E. (2004). Managing human resources in small organizations: what do we know? Human Resource Management Review, 14(3), 295-323. https://doi. org/10.1016/j.hrmr.2004.06.001

Carter, N. M., Gartner, W. B., \& Reynolds, P. D. (1996). Exploring start-up event sequences. Journal of Business Venturing, 11(3), 151-166. https://doi.org/10.1016/0883-9026(95)00129-8

Cassar, G., \& Ittner, C. D. (2009). Initial retention of external accountants in startup ventures. European Accounting Review, 18(2), 313-340. https://doi.org/10.1080 /09638180902731562

Chandler, G. N., Honig, B., \& Wiklund, J. (2005). Antecedents, moderators, and performance consequences of membership change in new venture teams. Journal of Business Venturing, 20(5), 705-725. https://doi.org/10.1016/j.jbusvent.2004.09.001

Chandler, G. N., Mckelvie, A., \& Davidsson, P. (2009). Asset specificity and behavioral uncertainty as moderators of the sales growth - employment growth relationship in emerging ventures. Journal of Business Venturing, 24(4), 373-387. https://doi.org/10.1016/j.jbusvent.2008.04.002

Coad, A., Nielsen, K., \& Timmermans, B. (2016). My first employee: an empirical investigation. Small Business Economics, (July). https://doi.org/10.1007/s11187-016-9748-3.

Colombo, M. G., \& Grilli, L. (2005). Founders' human capital and the growth of new technology-based firms: a competencebased view. Research Policy, 34(6), 795-816. https://doi. org/10.1016/j.respol.2005.03.010

Cooper, A. C., Gimeno-Gascon, F. J., Woo, C. Y., \& Cooper, A. (1994). Initial human and financial capital as predictors of new venture performance. Journal of Business Venturing, 9(5), 371-395. https://doi.org/10.1016/0883-9026(94)90013-2

Cooper, A. C., Woo, C. Y., \& Dunkelberg, W. C. (1989). Entrepreneurship and the initial size of firms. Journal of Business Venturing, 4(5), 317-332. https://doi.org/10.1016 /0883-9026(89)90004-9

Dahl, M. S., Klepper, S., M, C. N., \& D, C. (2015). Whom do new firms hire? Industrial and Corporate Change, 24(4), 819836. https://doi.org/10.1093/icc/dtv026

Davidsson, P., \& Gordon, S. R. (2012). Panel studies of new venture creation: a methods-focused review and suggestions for future research. Small Business Economics, 39(4), 853876. https://doi.org/10.1007/s11187-011-9325-8

Davidsson, P., \& Henrekson, M. (2002). Determinants of the prevalance of start-ups and high-growth firms. Small Business Economics, 19(2), 81-104. https://doi.org/10.1023 /A:1016264116508

Delmar, F., \& Shane, S. (2003). Does business planning facilitate the development of new ventures? Strategic Management Journal, 24(12), 1165-1185. https://doi.org/10.1002/smj.349

Delmar, F., \& Shane, S. (2004). Legitimating first: organizing activities and the survival of new ventures. Journal of Business Venturing, 19(3), 385-410. https://doi.org/10.1016 /S0883-9026(03)00037-5

Dilli, S., Elert, N., \& Herrmann, A. M. (2018). Varieties of entrepreneurship: exploring the institutional foundations of different entrepreneurship types through "Varieties-of-Capitalism" arguments. Small Business Economics.

Eisenhardt, K. M., Bird, C., Aldrich, H., Anderson, P., Cameron, K., Freeman, J., et al. (1990). Organizational growth: linking founding team, strategy, environment, and growth among U.S. semiconductor ventures, 1978-1988. Administrative Science Quarterly, 35(3), 504-529. https://doi.org/10.2307 $/ 2393315$

Estévez-Abe, M., \& Iversen, T. (2001). Social protection and the formation of skills: a reinterpretation of the welfare state. In P. A. Hall \& D. Soskice (Eds.), Varieties of capitalism - the institutional foundations of comparative advantage (pp. 145-183). Oxford: Oxford University Press. https://doi. org/10.1093/0199247757.003.0004

Folta, T. B., Delmar, F., \& Wennberg, K. (2010). Hybrid entrepreneurship. Management Science, 56(2), 253-269. https://doi. org/10.1287/mnsc.1090.1094

Freel, M. S., \& Robson, P. J. A. (2004). Small firm innovation, growth and performance: evidence from Scotland and northern England. International Small Business Journal, 22(6), 561-575. https://doi.org/10.1177/0266242604047410

Fritsch, M., \& Weyh, A. (2006). How large are the direct employment effects of new businesses? An empirical investigation for West Germany. Small Business Economics, 27(2-3), 245-260. https://doi.org/10.1007/s11187-006-0005-z

Garnsey, E., Stam, E., \& Heffernan, P. (2006). New firm growth: exploring processes and paths. Industry \& Innovation, 13(1), 1-20. https://doi.org/10.1080/13662710500513367

Gartner, W. B. (1988). "Who is an entrepreneur" is the wrong question. American Journal of Small Business, 12(4), 11-32.

Gartner, W. B., Carter, N. M., \& Reynolds, P. D. (2004). Business start-up activities. In Handbook of entrepreneurial dynamics the process of business creation (pp. 285-298). Sage Publications Ltd. https://doi.org/10.4135/9781452204543.n26.

Gartner, W. B., \& Shaver, K. G. (2012). Nascent entrepreneurship panel studies: progress and challenges. Small Business Economics, 39(3), 659-665. https://doi.org/10.1007 /s11187-011-9353-4

Gatewood, E. J., Shaver, K. G., \& Gartner, W. B. (1995). A longitudinal study of cognitive factors influencing start-up behaviors and success at venture creation. Journal of Business Venturing, 10(5), 371-391. https://doi.org/10.1016 /0883-9026(95)00035-7

Gordon, S. R. (2012). Dimensions of the venture creation process : Amount, dynamics, and sequences of action in nascent entrepreneurship.

Gordon, S. R., \& Davidsson, P. (2013). Unpacking the venture creation process (No. 7). Brisbane.

Grant, R. M. (1997). The knowledge-based view of the firm: implications for management practice. Long Range Planning, 30(3), 450-454. https://doi.org/10.1016/S00246301(97)00025-3

Hall, P. A., \& Soskice, D. (2001a). Varieties of capitalism: The institutional foundations of comparative advantage. OUP Oxford. https://doi.org/10.1093/0199247757.001.0001.

Hall, P. A., \& Soskice, D. (2001b). An introduction to varieties of capitalism. In P. A. Hall \& D. Soskice (Eds.), Varieties of capitalism: the institutional foundations of comparative advantage (pp. 1-71). Oxford: Oxford University Press. https://doi.org/10.1093/0199247757.003.0001

Halpin, B. (2010). Optimal matching analysis and life-course data: the importance of duration. Sociological Methods \& Research, 38(3), 365-388. https://doi.org/10.1177 $/ 0049124110363590$ 
Hellerstedt, K. (2009). The composition of new venture teams its dynamics and consequences. Jönköping International Business School.

Henrekson, M., Johansson, D., \& Stenkula, M. (2010). Taxation, labor market policy and high-impact entrepreneurship. Journal of Industry, Competition and Trade, 10(3-4), 275296. https://doi.org/10.1007/s10842-010-0081-2

Herrmann, A. M., \& Peine, A. (2011). When "national innovation system" meet "varieties of capitalism" arguments on labour qualifications: on the skill types and scientific knowledge needed for radical and incremental product innovations. Research Policy, 40(5), 687-701. https://doi.org/10.1016/j. respol.2011.02.004

Hjorth, D., Holt, R., \& Steyaert, C. (2015). Entrepreneurship and process studies. International Small Business Journal, 33(6), 599-611. https://doi.org/10.1177/0266242615583566

Jaspers, F., \& Hak, T. (2013). The sequence of gestation activities and its impact on achieving sustained sales. In DRUID Celebration Conference 2013.

Kaulio, M. A. (2003). Initial conditions or process of development? Critical incidents in the early stages of new ventures. R\&D Management, 33(2), 165. https://doi.org/10.1111/14679310.00290

Kazanjian, R. K., \& Drazin, R. (1990). A stage-contingent model of design and growth for technology based new ventures. Journal of Business Venturing, 5(3), 137-150. https://doi. org/10.1016/0883-9026(90)90028-R

Koch, A., Späth, J., \& Strotmann, H. (2013). The role of employees for post-entry firm growth. Small Business Economics, 41(3), 733-755. https://doi.org/10.1007/s11187-012-9456-6

Langley, A., Montréal, H., Smallman, C., \& Vandeven, A. H. (2013). Process studies of change in organization and management: unveiling temporality, activity and flow. Academy of Management Journal, 56(1), 1-13. https://doi.org/10.5465 /amj.2013.4001

Levie, J., \& Lichtenstein, B. B. (2010). A terminal assessment of stages theory: introducing a dynamic states approach to entrepreneurship. Entrepreneurship: Theory and Practice, 34(2), 317-350. https://doi.org/10.1111/j.1540-6520.2010.00377.x

Liao, J., \& Welsch, H. (2008). Patterns of venture gestation process: exploring the differences between tech and non-tech nascent entrepreneurs. Journal of High Technology Management Research, 19(2), 103-113. https://doi. org/10.1016/j.hitech.2008.10.003

Liao, J., Welsch, H., \& Tan, W. L. (2005). Venture gestation paths of nascent entrepreneurs: exploring the temporal patterns. Journal of High Technology Management Research, 16(1), 1-22. https://doi.org/10.1016/j.hitech.2005.06.001

Mascitelli, R. (2000). From experience: harnessing tacit knowledge to achieve breakthrough innovation. Journal of Product Innovation Management, 17(3), 179-193. https://doi. org/10.1016/S0737-6782(00)00038-2

McMullen, J. S., \& Dimov, D. (2013). Time and the entrepreneurial journey: the problems and promise of studying entrepreneurship as a process. Journal of Management Studies, 50(8), 1481-1512. https://doi.org/10.1111/joms.12049

Melillo, F., Folta, T. B., \& Delmar, F. (2013). What determines the initial size of new ventures? In DRUID Celebration Conference 2013.

Metzger, G. (2014). Gründungstätigkeit wiederbelebt - Impuls aus dem Nebenerwerb.
Moroz, P. W., \& Hindle, K. (2012). Entrepreneurship as a process: toward harmonizing multiple perspectives. Entrepreneurship: Theory \& Practice, 36(4), 781-818. https://doi.org/10.1111 j.1540-6520.2011.00452.x

Parker, S. C. (2010). Contracting out, public policy and entrepreneurship. Scottish Journal of Political Economy, 57(2), 119144. https://doi.org/10.1111/j.1467-9485.2010.00510.x

Petrova, K. (2012). Part-time entrepreneurship and financial constraints: evidence from the panel study of entrepreneurial dynamics. Small Business Economics, 39(2), 473-493. https://doi.org/10.1007/s11187-010-9310-7

Phelps, R., Adams, R. J., \& Bessant, J. (2007). Life cycles of growing organizations: a review with implications for knowledge and learning. International Journal of Management Reviews, 9(1), 1-30. https://doi.org/10.1111/j.14682370.2007.00200.x

Pollock, G. (2007). Holistic trajectories: a study of combined employment, housing and family careers by using multiplesequence analysis. Journal of the Royal Statistical Society: Series A (Statistics in Society), 170(1), 167-183. https://doi. org/10.1111/j.1467-985X.2006.00450.x

Poole, M. S., van de Ven, A. H., Dooley, K., \& Holmes, M. E. (2000). Organizational change and innovation processes: theory and methods for research. New York, NY: Oxford University Press.

Raffiee, J., \& Feng, J. (2014). Should I quit my day job? A hybrid path to entrepreneurship. Academy of Management Journal, 57(4), 936-963. https://doi.org/10.5465/amj.2012.0522

Reynolds, P., \& Miller, B. (1992). New firm gestation: conception, birth, and implications for research. Journal of Business Venturing, 7(5), 405-417. https://doi.org/10.1016/08839026(92)90016-K

Reynolds, P., \& White, S. B. (1997). The entrepreneurial process. Westport: Quorum Books.

Román, C., Congregado, E., \& Millán, J. M. (2011). Dependent self-employment as a way to evade employment protection legislation. Small Business Economics, 37(3), 363-392. https://doi.org/10.1007/s11187-009-9241-3

Román, C., Congregado, E., \& Millán, J. M. (2013). Start-up incentives: entrepreneurship policy or active labour market programme? Journal of Business Venturing, 28(1), 151-175. https://doi.org/10.1016/j.jbusvent.2012.01.004

Ruef, M. (2005). Origins of organizations: The entrepreneurial process. In L. A. Keister (Ed.), Entrepreneurship (Research in the Sociology of Work, Volume 15) (pp. 63-100). Emerald Group Publishing Limited. https://doi.org/10.1016/S02772833(05)15004-3.

Samuelsson, M., \& Davidsson, P. (2009). Does venture opportunity variation matter? Investigating systematic process differences between innovative and imitative new ventures. Small Business Economics, 33(2), 229-255. https://doi. org/10.1007/s11187-007-9093-7

Stovel, K., \& Bearman, P. (1996). Ascription into achievement: models of career systems at Lloyds. American Journal of Sociology, 102(2), 1890-1970. https://doi.org/10.1086/230950

Ucbasaran, D., Lockett, A., Wright, M., \& Westhead, P. (2003). Entrepreneurial founder teams: factors associated with member entry and exit. Entrepreneurship Theory and Practice, 28(2), 107-128. https://doi.org/10.1046/j.15406520.2003.00034.x 
Van de Ven, A. H., \& Engleman, R. M. (2004). Event- and outcome-driven explanations of entrepreneurship. Journal of Business Venturing, 19(3), 343-358. https://doi. org/10.1016/S0883-9026(03)00035-1

van Stel, A., Storey, D. J., \& Thurik, A. R. (2007). The effect of business regulations on nascent and young business entrepreneurship. Small Business Economics, 28(2-3), 171-186. https://doi.org/10.1007/s11187-006-9014-1

Virtanen, M., Kivimäki, M., Virtanen, P., Elovainio, M., \& Vahtera, J. (2003). Disparity in occupational training and career planning between contingent and permanent employees. European Journal of Work and Organizational Psychology, 12(1), 1936. https://doi.org/10.1080/13594320344000002

Weber, A., \& Zulehner, C. (2010). Female hires and the success of start-up firms. The American Economic Review, 100(2), 358361. https://doi.org/10.1257/aer
Wennberg, K., Folta, T. B., \& Delmar, F. (2006). A real options model of stepwise entry into self- employment. Frontiers of Entrepreneurship Research, 26(6), 1-13. https://doi. org/10.2139/ssrn.1310937

Wennekers, S., Van Wennekers, A., Thurik, R., \& Reynolds, P. (2005). Nascent entrepreneurship and the level of economic development. Small Business Economics, 24(3), 293-309. https://doi.org/10.1007/s11187-0051994-8

Wiersema, M. F., \& Bantel, K. A. (1992). Top management team demography and corporate strategic change. The Academy of Management Journal, 35(1), 91-121. https://doi.org/10.2307 1256474 